\title{
Electrochemical Corrosion Testing of Neutron Absorber Materials
}

\author{
Tedd Lister \\ Ron Mizia \\ Sandra Birk \\ Brent Matteson \\ Hongbo Tian
}

October 2006

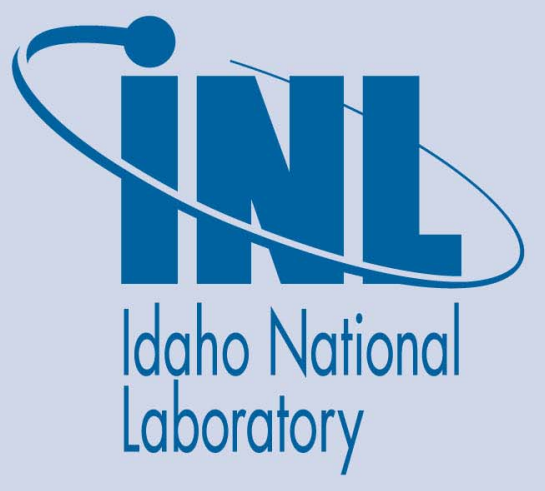

The INL is a U.S. Department of Energy National Laboratory operated by Battelle Energy Alliance 


\title{
Electrochemical Corrosion Testing of Neutron Absorber Materials
}

\author{
Tedd Lister \\ Ron Mizia \\ Sandra Birk \\ Brent Matteson \\ Hongbo Tian
}

October 2006

\section{Idaho National Laboratory \\ Idaho Falls, Idaho 83415}

Prepared for the

U.S. Department of Energy

Office of Nuclear Energy

Under DOE Idaho Operations Office

Contract DE-AC07-05ID14517 


\section{Introduction}

The Yucca Mountain Project (YMP) has been directed by DOE-RW to develop a new repository waste package design based on the transport, aging, and disposal canister (TAD) system concept. A neutron poison material for fabrication of the internal spent nuclear fuel (SNF) baskets for these canisters needs to be identified. A material that has been used for criticality control in wet and dry storage of spent nuclear fuel is borated stainless steel. ${ }^{1}$ These stainless products are available as an ingot metallurgy plate product with a molybdenum addition $^{2}$ and a powder metallurgy product ${ }^{3}$ that meets the requirements of ASTM A887, Grade A. A new Ni-Cr-Mo-Gd alloy ${ }^{4}$ has been developed by the Idaho National Laboratory (INL) with its research partners (Sandia National Laboratory and Lehigh University) with DOE-EM funding provided by the National Spent Nuclear Fuel Program (NSNFP). This neutron absorbing alloy will be used to fabricate the SNF baskets in the DOE standardized canister. The INL has designed the DOE Standardized Spent Nuclear Fuel Canister ${ }^{5}$ for the handling, interim storage, transportation, and disposal in the national repository of DOE owned spent nuclear fuel (SNF). A corrosion testing program is required to compare these materials in environmental conditions representative of a breached waste canister.

This report will summarize the results of crevice corrosion tests for three alloys in solutions representative of ionic compositions inside the waste package should a breech occur. The three alloys in these tests are Neutronit A978 (ingot metallurgy, hot rolled), Neutrosorb 304B4 Grade $\mathrm{A}^{3}$ (powder metallurgy, hot rolled), and Ni-Cr-Mo-Gd alloy ${ }^{4}$ (ingot metallurgy, hot rolled).

\section{Material Descriptions}

\section{Borated Stainless Steel}

\section{Physical Metallurgy}

The borated stainless steel alloys solidify as primary austenite with a terminal eutectic constituent with the form $\mathrm{Fe}_{2} \mathrm{~B}, \mathrm{Cr}_{2} \mathrm{~B}$ with the exact composition dependent on the initial boron level $^{6}$ as shown in Figure 1. The austenite matrix is a ductile phase and the dispersed secondary phase is a comparatively brittle compound.

\footnotetext{
1 "Standard Specification for Borated Stainless Steel Plate, Sheet, and Strip for Nuclear Application," ASTM A88789, American Society for Testing and Materials (2004).

${ }^{2}$ Bohler Bleche GmbH, P.O. Box 28, Murzzuschlag, Austria

${ }^{3}$ Carpenter Technology Corp. P.O Box 14662, Reading, PA

4 "Standard Specification for Low-Carbon Nickel-Chromium-Molybdenum-Gadolinium Alloy Plate, Sheet, and Strip,” ASTM B932-04, American Society for Testing and Materials (2004).

${ }^{5}$ Preliminary Design Specification for Department of Energy Standardized Spent Nuclear Fuel Canisters, Volume I - Design Specification, DOE/SNF/REP-011, Revision 3, August 17, 1999.

${ }^{6}$ H.J. Goldschmidt, "Effect of Boron Additions to Austenitic Stainless Steels Part II, Solubility of Boron in $18 \%$ Cr, 15\% Ni Austenitic Steel,” Journal of the Iron and Steel Institute, November 1971, page 910.
} 


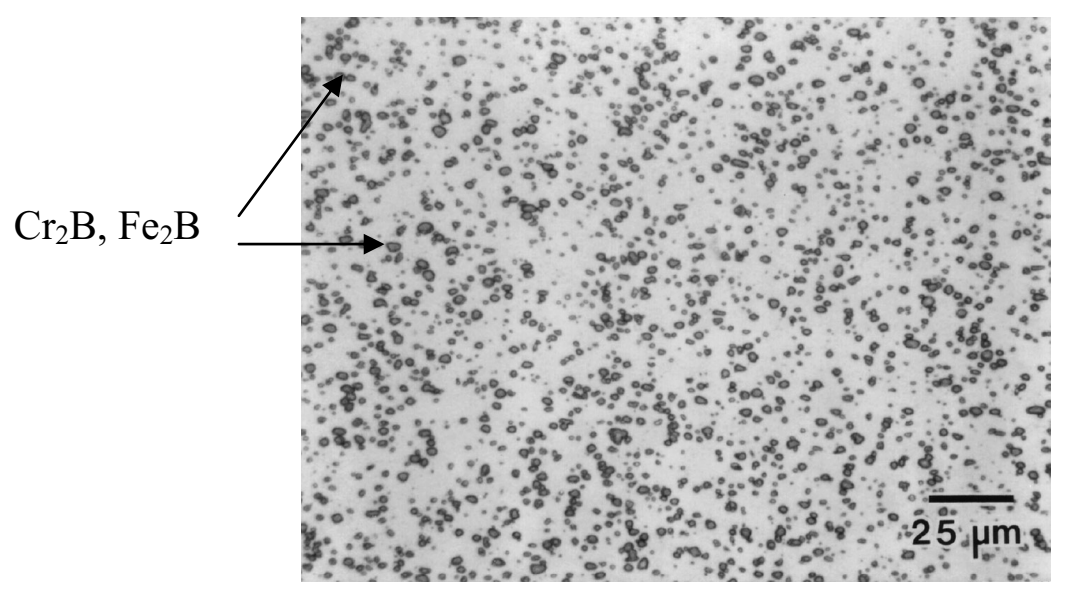

Figure 1: 304B4A (1.16 wt\% B), powder metallurgy, hot rolled

\section{ASTM and ASME Standards}

Borated stainless steels are defined in ASTM A887 where there are eight types (304B 304B7) which define boron concentrations from 0.2 to $2.25 \mathrm{wt} \% \mathrm{~B}$. There are two grades (A \& B) defined where requirements are controlled by mechanical properties (Charpy impact energy). These requirements essentially define the alloy processing where Grade A alloys are powder metallurgy products and Grade B alloys are ingot metallurgy products. There are sixteen discrete alloys specified in A887.

\section{Ni-Cr-Mo-Gd Alloys}

\section{Physical Metallurgy}

A typical microstructure for the Ni-Cr-Mo-Gd alloy is shown in Figure 2. The microstructure consists of a Ni-Cr-Mo austenitic matrix with a composition similar to UNS N06455 (darker structure) and a dispersed secondary phase (lighter structure) with a hexagonal crystal structure based on the $\mathrm{Ni}_{5} \mathrm{Gd}$ gadolinide. This secondary phase is generally found at the austenite grain boundaries. The $\mathrm{Ni}_{5} \mathrm{Gd}$ phase also contains small amounts of dissolved chromium and molybdenum (on the order of $1 \mathrm{wt} \%$ ). The size, shape, and distribution of the secondary phase evolves from its initial solidification morphology in the interdendritic regions of the ascast ingot through hot rolling and heat treatment to the wrought structure illustrated here. Gadolinium has extremely limited solubility in the nickel austenite matrix and has not been detected there. In general, the alloy can be described as one containing a hard dispersed secondary phase within a softer, ductile austenitic matrix. 


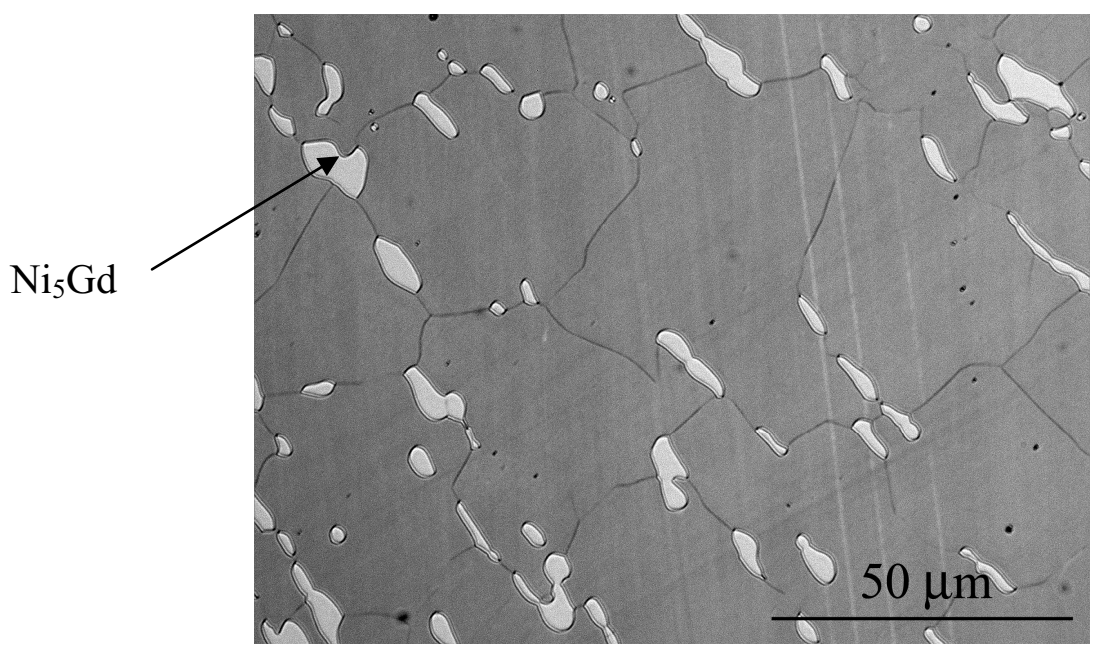

Figure 2 : Ni-Cr-Mo-Gd alloy microstructure

\section{ASTM and ASME Standards}

The Ni-Cr-Mo-Gd alloy chemistry requirements are defined in ASTM B932-04. ${ }^{\text {Error! }}$ Bookmark not defined. The mechanical and physical property requirements and ASME design allowables are defined in ASME Code Case N-728. ${ }^{7}$

\section{Experimental}

\section{Specimens}

The A978 specimens were refinished from coupons previously used for YMP corrosion studies by Lawrence Livermore National Laboratory (LLNL) (Heats E084295 and N156129). ${ }^{8}$ These specimens were used for long-term immersion tests and were not designed for electrochemical testing. The size of the furnished specimens did not allow fabrication of the crevice specimens used for the other alloys. The 304B4 and Ni-Cr-Mo-Gd (also known as C4$\mathrm{Gd}$ ) alloys were plate stock. Table 1 shows the composition of these alloys.

\footnotetext{
${ }^{7}$ ASME Boiler and Pressure Vessel Code, Section III, Division 3, "Containment Systems and Transport Packagings for Spent Nuclear Fuel and High-Level Radioactive Waste," The American Society of Mechanical Engineers, New York, NY, 2002. Case N-728, Use of B-932-04 plate material for non-pressure retaining spent-fuel containment internals to 650F (343C), Section III, Division 3, May 10, 2005

${ }^{8}$ D.V. Fix, J.C. Estill, L.L. Wong, and R.B. Rebak, "General and Localized Corrosion of Austenitic and Borated Stainless Steels in Simulated Concentrated Ground Waters," American Society of Mechanical Engineers Pressure Vessels and Piping Division (ASME-PVP) Conference, San Diego, CA. July 2004
} 
Table 1: Alloy composition (wt $\%)$

\begin{tabular}{|c|c|c|c|c|}
\hline $\begin{array}{l}\text { Alloy } \\
\text { Heat \# } \\
\text { Name }\end{array}$ & $\begin{array}{c}\text { 304B4 Grade A } \\
\text { 182194 } \\
\text { 304B4 }\end{array}$ & $\begin{array}{c}\text { ASTM B 932-04 } \\
\text { (Ni-Cr-Mo-Gd) } \\
\text { D5-8235 } \\
\text { C4-Gd }\end{array}$ & $\begin{array}{c}\text { Neutronit } \\
\text { A978 Error! Bookmark not } \\
\text { defined. } \\
\text { N156129 } \\
\text { SSN }\end{array}$ & $\begin{array}{c}\text { Neutronit A978 } \\
\text { Bookmarkor! } \\
\\
\text { E08429 defined. } \\
\text { SSE }\end{array}$ \\
\hline $\mathrm{Cr}$ & 19.70 & 16.75 & 19.16 & 18.18 \\
\hline $\mathrm{Ni}$ & 13.70 & Bal. & 12.74 & 12.07 \\
\hline Mo & - & 14.43 & 2.22 & 2.11 \\
\hline B & 1.16 & - & 1.17 & 1.00 \\
\hline $\mathrm{Gd}$ & - & 1.89 & - & - \\
\hline$C$ & 0.05 & 0.003 & 0.039 & 0.056 \\
\hline $\mathrm{Mn}$ & 1.78 & $<0.01$ & .097 & 1.70 \\
\hline $\mathrm{Cu}$ & - & - & 0.10 & 0.35 \\
\hline $\mathrm{Fe}$ & Bal & $<0.01$ & Bal & Bal \\
\hline
\end{tabular}

Specimens of the 304B4 material and Ni-Cr-Mo-Gd alloys were machined from plate stock. The crevice specimen design is based on LLNL specimen design and is a controlled INL document. ${ }^{9}$ The $304 \mathrm{~B} 4$ and Ni-Cr-Mo-Gd specimens were 0.75 " X 0.75 " X 0.375 " with a 0.28 " through-hole for the crevice assembly. The A978 specimens obtained from LLNL were approximately 1 " X 1 " X 0.125 " with a 0.3 " through-hole for the crevice assembly. The specimens were wet sanded with 240 and 600 grit sandpaper the day of testing.

The crevice formers used in the test were multiple crevice assembly (MCA) type made of ceramic. The surfaces were wet sanded with 600 grit sandpaper to smooth the as-received surfaces. The crevice formers were attached to the specimens with fasteners made of alloy C276. Teflon tape was wrapped on the crevice bolt to electrically isolate from the specimen. A torque of 50 in-oz was applied to the crevice bolt for all tests.

A special electrical contact was needed for the A978 specimens due to the lack of width for a conventional attachment. Pt wire was spot welded to the specimen surface and a wire soldered to the Pt. The exposed wires were isolated using epoxy designed for submersed conditions. Problems with the epoxy occurred in some tests as will be discussed in the results section. A second set of tests were performed using a Pt wire spot welded to the specimen extending outside the cell without any coating. This appeared to affect the results and will be discussed below.

\section{Solutions}

The compositions of the three solutions used in these tests are shown in Table 2. These compositions were supplied by YMP technical staff. These solutions are based on expected compositions (major ions) for in-package chemistry. Each solution was mixed in a large batch such that all solutions of that type were the same. Chemicals were ACS grade and used exclusively for this work. The nitrate to chloride and nitrate to halide ratios are calculated for comparison purposes. For this work only solutions B1 and B3 were tested.

\footnotetext{
${ }^{9}$ INL DWG 630285, Crevice Corrosion Specimen, March 15, 2005.
} 
Table 2: Solution compositions

\begin{tabular}{|c|c|c|c|c|c|c|}
\hline $\begin{array}{c}\text { Test } \\
\text { Solution }\end{array}$ & {$[\mathbf{C l}] \mathbf{( m )}$} & {$[\mathbf{F}](\mathbf{m})$} & {$\left[\mathrm{NO}_{3}\right] \mathbf{( m )}$} & $\mathbf{p H}$ & $\mathbf{N O}_{3} / \mathbf{C l}$ & $\mathbf{N O}_{3} /(\mathbf{C l}+\mathbf{F})$ \\
\hline B1 & 0.004 & 0 & 0.005 & 7 & 1.25 & 1.25 \\
\hline B2 & 0.004 & 0.001 & 0.005 & 5.5 & 1.25 & 1.00 \\
\hline B3 & 0.004 & 0.001 & 0.0025 & 5.5 & 0.63 & 0.50 \\
\hline
\end{tabular}

\section{Testing Procedures}

The testing procedures are contained within INL document PLN-1885. ${ }^{10}$ The cell was similar to that described in ASTM G5, Figure 3. ${ }^{11}$ All tests were performed at $60^{\circ} \mathrm{C}$ maintained by a thermocouple based temperature controller. The heating was supplied by a mantle under the cell. The temperature of the cell was confirmed using a calibrated thermometer before the initiation of each test. The cell was fitted with a condenser to prevent solution loss during the test. Chilled water $\left(5^{\circ} \mathrm{C}\right)$ was passed through the condenser. The reference electrode was contained in a water-chilled Luggin capillary. A single graphite rod was employed as the counter electrode. Other experimental details are provided below.

\section{Results and Discussion}

\section{Potentiodynamic tests}

Potentiodynamic tests (PD) were performed in solution B1 as a preliminary investigation of the corrosion properties of these materials. These tests were performed consistent with ASTM G5 testing. A cyclic potential profile was used to investigate the repassivation characteristics of the materials on the return sweep. Heat E084295 (SSE) was used for the A978 specimen. The PD test was initiated after performing a 50 minute corrosion potential $\left(\mathrm{E}_{\text {corr }}\right)$ measurement with $\mathrm{N}_{2}$ purge. The PD scan was initiated $-0.2 \mathrm{~V}$ negative of the measured $\mathrm{E}_{\text {corr }}$ and reversed at $+0.8 \mathrm{~V}$ vs SCE. The scan rate was $0.166 \mathrm{mV} / \mathrm{sec}$. Note that the electrical contact for the A978 specimen in this short period test did not appear to be compromised as was the case for later PS tests and therefore the data is included here.

PD curves of the three specimens are shown in Figure 3 with the $\mathrm{E}_{\text {corr }}$, breakdown potentials $\left(\mathrm{E}_{\mathrm{bd}}\right)$ and repassivation $\left(\mathrm{E}_{\mathrm{rp}}\right)$ values provided. The A978 specimen had a breakdown value (using a $10 \mu \mathrm{A} / \mathrm{cm}^{2}$ criteria, see dashed blue line on the plot) approximately $0.2 \mathrm{~V}$ negative of 304B4 specimen indicating a greater tendency to pitting. The $\mathrm{E}_{\mathrm{bd}}$ value for C4-Gd is very close to the $\mathrm{E}_{\text {corr }}$ value indicating a very reactive surface due to the initial gadolinide dissolution. The $\mathrm{E}_{\mathrm{rp}}$ value (using the crossover criteria) for A978 is about $0.14 \mathrm{~V}$ more negative than 304B4 indicating a reduced tendency to repassivate as compared to the 304B4 specimen under these conditions. The total current passed during breakdown is also much greater for the A978. The C4-Gd has much higher current in the forward sweep but a reduction in that current during the reverse sweep. Thus no $\mathrm{E}_{\mathrm{rp}}$ value applies. The measurements are consistent with the observations of the specimen as will be discussed below.

\footnotetext{
${ }^{10}$ PLN-1885, Rev 2, “Experimental Procedures for Corrosion Testing of Ni-Cr-Mo-Gd Alloys”, Sept. 1, 2005.

11 "Standard Reference Test Method for Making Potentiostatic and Potentiodynamic Anodic Polarization Measurements," ASTM G5-94, American Society for testing and Materials (2004).
} 
Photographs of the specimens after the PD testing are shown in Figure 4. The specimens showed attack primarily at the base metal/MCA teeth interface. The A978 specimen showed much greater amount of crevice attack, with 20 of the 24 teeth showing crevice attack. The 304B4 showed attack in 9 of the 24 teeth with the total damage area/damaged area under the MCA teeth being lower. The C4-Gd alloy does not show any extensive etching or pitting under the crevice teeth. There are stains outside the crevice regions. These are likely due to corrosion products leeching from within the crevice areas (lower $\mathrm{pH}$ ) and precipitating in high $\mathrm{pH}$ regions.

Light optical microscopy (LOM) images of the specimens are shown in Figure 5. It is apparent that significant crevice corrosion occurred under the MCA teeth of the borated stainless steel specimens. The damage was more pronounced on the A978 specimen. There was also pitting outside the crevice area (Figure 5B-C) on the A978 specimen while none was observed on the 304B4 specimen. The C4-Gd alloy had the gadolinide particles removed which resulted in the large current observed in the forward sweep. As an additional part of the C4-Gd test, linear polarization resistance (LPR) sweeps were performed before and after the PD sweep. The corrosion rate before the sweep was $405 \mu \mathrm{m} / \mathrm{yr}$ and dropped to $8.10 \mu \mathrm{m} / \mathrm{yr}$ after the test. This decrease was due to removal of surface gadolinides. More details of the LPR sweep methods will be provided in the PS section below.

The superior performance of the 304B4 specimen over the A978 appears to be a metallurgical phenomenon. The A978 material is an ingot metallurgy product and thus will have larger, more elongated secondary phase $\left(\mathrm{Cr}_{2} \mathrm{~B}\right)$ particles while the Neutrosorb Grade A product will have a more uniformly distributed, rounded, secondary phase. ${ }^{12}$ The $\mathrm{C} 4-\mathrm{Gd}$ alloy shows a superior resistance to base material attack as evidenced by the lack of substantial crevice attack. The higher resistance to crevice corrosion is related to the Ni-based composition of the C4-Gd alloy.

${ }^{12}$ C.V. Robino and M.J. Cieslak, "High Temperature Metallurgy of Advanced Borated Stainless Steels", Metallurgical and Materials Transactions A, 26 (1995) 1673. 


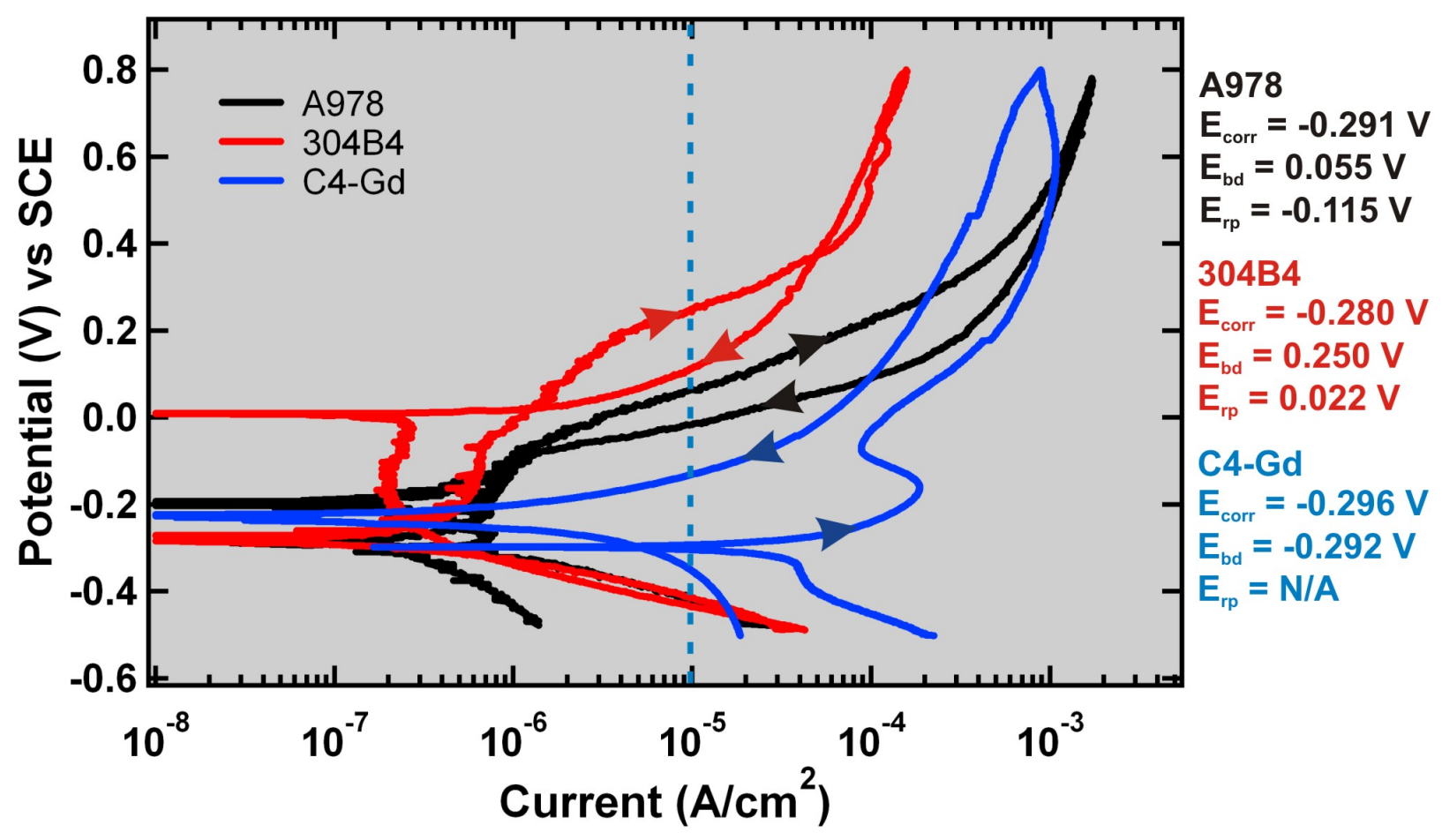

Figure 3: PD curves for the three alloys in solution B1.

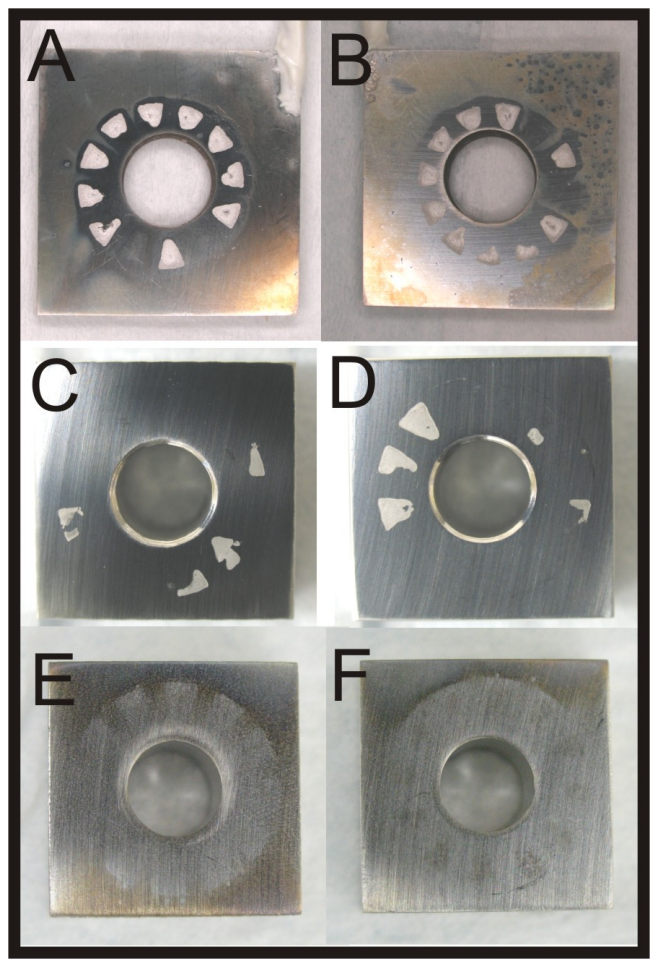

Figure 4: Macro photographs of A978 (A-B), 304B4 (C-D) and C4-Gd (E-F) after PD testing. 


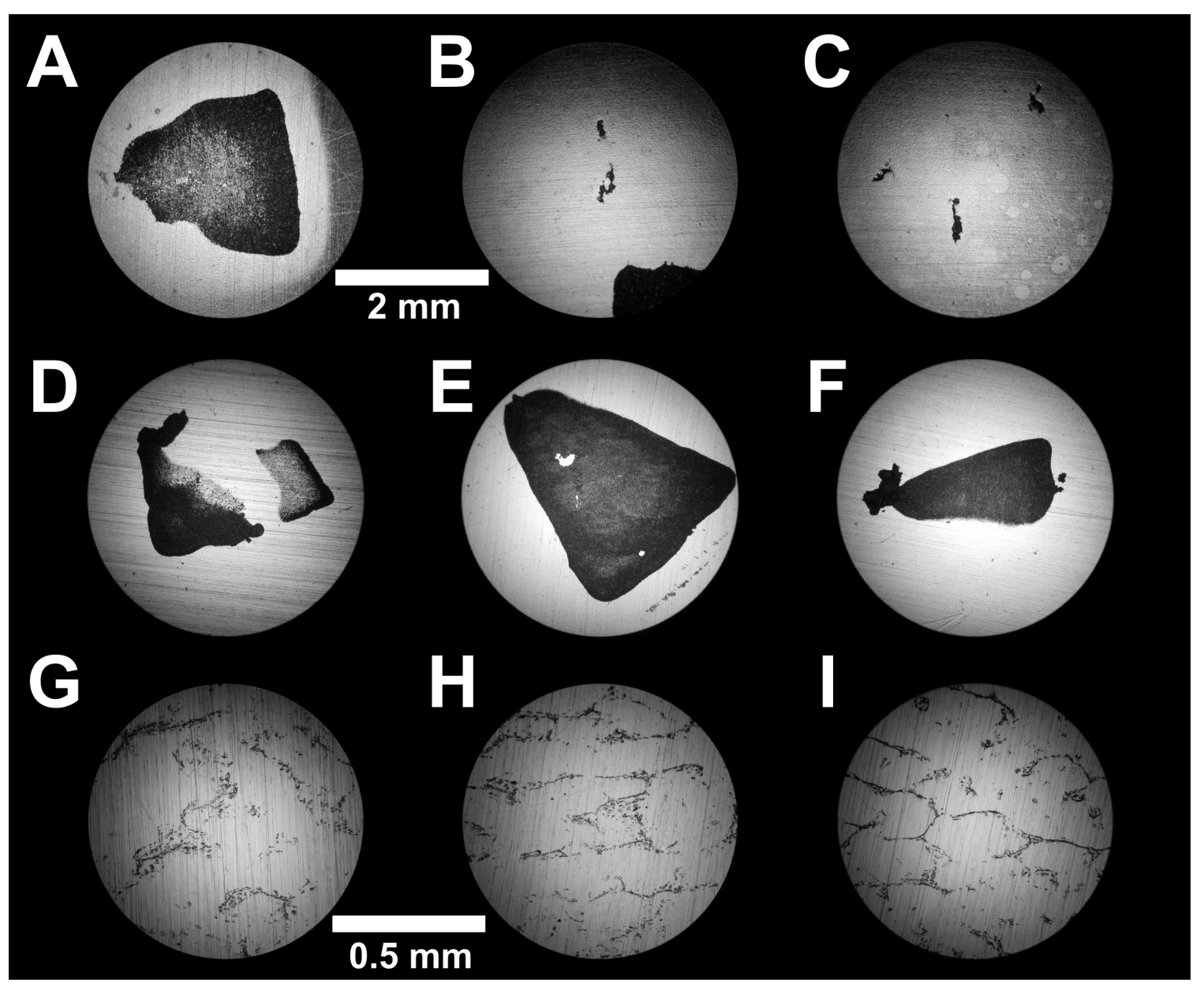

Figure 5: LOM images taken at 50X magnification factor for A978 (A-C) and 304B4 (D-F) and at $200 \mathrm{X}$ magnification factor of C4-Gd (G-I) after PD testing.

\section{Potentiostatic tests}

\section{PS test introduction}

Potentiostatic tests (PS) were used to determine the corrosion performance of the alloys over longer periods of time. In the case where no localized corrosion occurs, the current from the PS tests is directly proportional to the general corrosion rate. In the event that localized corrosion occurs during the PS test, the situation is not as straightforward. As localized corrosion by definition is not a uniform mechanism, the rate will not have the same meaning but is still proportional to the amount of material being removed. The rate is reported as a general corrosion rate in either case. The basis for calculation of the corrosion rate from the corrosion current ( $\left.\mathrm{i}_{\text {corr }}\right)$ can be found in ASTM G102 $2^{13}$ and is derived from the Faraday's Law. As stated above, the corrosion rate assumes a uniform loss of material which does not occur with localized processes such as pitting, crevice corrosion, or dissolution of a secondary phase (i.e. the gadolinide phase in the C4-Gd alloy).

\footnotetext{
13 "Standard Practice for Calculation of Corrosion Rates and Related Information from Electrochemical Measurements," ASTM G102-89, American Society for Testing and Materials (2004).
} 
The electrochemical potential chosen for the PS tests is based on that expected in the environment. This was determined by measuring the $\mathrm{E}_{\text {corr }}$ for 24 hours while saturating with air. This mimics the effect of maximum exposure of air, where oxygen acts as an oxidizer to shift the potentials of the materials in a positive direction. While general corrosion does not have a strong potential dependence localized corrosion initiation/propagation tends to increase with potential. The actual potential used for the tests was based on an early test for a 304B4 specimen where the $\mathrm{E}_{\text {corr }}$ value appeared to equilibrate to between 0 and $0.1 \mathrm{~V}$. Thus while most of the tests were performed at $0.1 \mathrm{~V}, 0.2 \mathrm{~V}$ was also tested as higher aerated $\mathrm{E}_{\text {corr }}$ values for 304B4 were observed in other tests.

The PS curves obtained from these measurements also provide qualitative information. Ideally, general corrosion is a smooth current flow that decreases exponentially during the test. This has been observed in long term corrosion testing of passive materials proposed for use by the YMP. ${ }^{14}$ Localized corrosion can be ascertained if there are increases in current during the test. Metastable pitting events, the origins of pitting or crevice corrosion, are characterized by short-lived positive spikes in the current trace. Longer lived events, beyond several seconds, are the result of sustained localized corrosion. The total charge is the integration of the current over the entire PS test. This provides a value for the total amount of material removed assuming the current is due to corrosion processes.

In addition, three linear polarization resistance (LPR) measurements were made just prior to the PS tests. These were performed after nitrogen degassing for 24 hours to allow equilibration. The test involves scanning the potential at a slow scan rate $(0.166 \mathrm{mV} / \mathrm{sec})$ from $30 \mathrm{mV}$ to $+30 \mathrm{mV}$ versus the measured $\mathrm{E}_{\text {corr. }}$ ASTM G59 ${ }^{15}$ describes the use of this technique in determining $i_{\text {corr }}$ at open circuit potential $\left(\mathrm{E}_{\text {corr }}\right)$ using the Butler-Volmer relationship. ${ }^{16}$ The slope of the curve is the polarization resistance $\left(R_{p}\right)$ and has units of $\Omega-\mathrm{cm}^{2}$. The value of $i_{\text {corr }}$ can be calculated if the Stern-Geary coefficient (B) is known. The three values were evaluated using the software package provided with the instrumentation. The linear portion of each curve was fit to determine the polarization resistance (slope of I-V curve). This was multiplied by the exposed surface area of the specimen. The value of B was estimated using Tafel slopes of $0.12 \mathrm{~V} / \mathrm{dec}$, yielding $\mathrm{B}=0.0261 \mathrm{~V}$. The $\mathrm{i}_{\text {corr }}$ was calculated using ASTM G59 Equation $2{ }^{15}$ The corrosion rate was calculated from $i_{\text {corr }}$ as described above for PS tests. A more advanced treatment uses a fitting procedure to determine the parameters in the event Tafel slopes are not known. ${ }^{17}$ The corrosion rate is then calculated from the calculated $i_{\text {corr }}$ values as described for PS tests above. Use of this method was not considered after very low cathodic Tafel slopes (below $5 \mathrm{mV} / \mathrm{dec}$ in most cases) were obtained. This is thought to be an issue with the software method of performing the sweep, where the step is immediately followed by the sweep. The fast drop in current and consequentially the low calculated Tafel slope is due to capacitive discharge of the interface. Future studies will use a delay before the sweep is initiated.

The data for PS tests are contained in Table 3. Data from A978 specimens is included as Appendix A. This should be referred to for the data sections that follow. In some cases, tests were interrupted by power failure (Tests 080806-1 and 080806-2) or problem with the reference

\footnotetext{
${ }^{14}$ BSC (Bechtel SAIC Company) 2004. General and Localized Corrosion of the Waste Package Outer Barrier, Las Vegas, Nevada.

15 "Standard Practice for Conducting Potentiodynamic Polarization Resistance Measurements," ASTM G59-97, American Society for Testing and Materials (2003).

${ }_{16}^{16}$ A.J. Bard and L.R. Faulkner, Electrochemical Methods, 2nd ed., Wiley, New York, 2001 Chapter 3.

${ }^{17}$ D.C. Silverman in Uhlig's Corrosion Handbook, $2^{\text {nd }}$ ed., Wiley, New York, 2000, pp 1197-1198.
} 
electrode (Tests 080906-1 and 082106). Data in those cases are not available (N/A) or what was available was used.

Table 3: Data obtained from electrochemical tests

\begin{tabular}{|c|c|c|c|c|c|c|c|c|c|}
\hline Test ID & Alloy & Solution & $\begin{array}{l}\text { Final } \\
\text { E }_{\text {corr }} \text { Ox } \\
\text { (V) }\end{array}$ & $\begin{array}{c}\text { Final } \\
\mathrm{E}_{\text {corr }} \mathrm{N}_{2} \\
\text { (V) }\end{array}$ & $\begin{array}{l}\text { Potential } \\
\text { (V) }\end{array}$ & $\begin{array}{l}\text { Total } \\
\text { Charge } \\
\left(\mathrm{C} / \mathrm{cm}^{2}\right)\end{array}$ & $\begin{array}{l}\text { Peak } \\
\text { Current } \\
\left(\mathrm{A} / \mathrm{cm}^{2}\right)\end{array}$ & $\begin{array}{c}\mathbf{i}_{\text {corr }} \\
\left(\mathrm{A} / \mathrm{cm}^{2}\right)\end{array}$ & $\begin{array}{c}\text { CR } \\
(\mu \mathrm{m} / \mathrm{yr})\end{array}$ \\
\hline 072406 & 304B4 & B1 & 0.0331 & -0.3011 & 0.1 & 4.44E-03 & 4.76E-06 & 3.42E-09 & 0.0325 \\
\hline 072506 & 304B4 & B3 & 0.0281 & -0.3972 & 0.1 & $5.68 \mathrm{E}-03$ & 6.69E-06 & 2.84E-09 & 0.0270 \\
\hline 072606 & 304B4 & B1 & 0.1781 & 0.04428 & 0.1 & $2.40 \mathrm{E}-03$ & 2.03E-07 & 2.54E-09 & 0.0242 \\
\hline 080806-1 & 304B4 & B1 & 0.0697 & -0.2493 & 0.1 & $\mathrm{~N} / \mathrm{A}$ & $N / A$ & $\mathrm{~N} / \mathrm{A}$ & $\mathrm{N} / \mathrm{A}$ \\
\hline 080806-2 & 304B4 & B1 & 0.1308 & -0.1203 & 0.2 & $\mathrm{~N} / \mathrm{A}$ & $\mathrm{N} / \mathrm{A}$ & $\mathrm{N} / \mathrm{A}$ & $\mathrm{N} / \mathrm{A}$ \\
\hline 080906-1 & 304B4 & B3 & 0.008 & -0.29 & 0.1 & 3.65E-2 & 1.12E-04 & $1.24 \mathrm{E}-8$ & 0.118 \\
\hline 081406 & C4-Gd & B1 & -0.3186 & -0.3264 & 0.1 & 4.01 & 2.26E-04 & $1.63 \mathrm{E}-06$ & 16.3 \\
\hline 081706 & C4-Gd & B3 & -0.259 & -0.277 & 0.1 & 1.85 & 8.08E-5 & $1.01 \mathrm{E}-6$ & 7.02 \\
\hline 082106 & C4-Gd & B1 & -0.3165 & -0.3193 & 0.2 & 1.62 & 3.87E-4 & $9.36 \mathrm{E}-6$ & 93.8 \\
\hline 082406 & C4-Gd & B3 & -0.2869 & -0.3005 & 0.2 & 2.19 & $1.32 \mathrm{E}-4$ & $3.49 \mathrm{E}-7$ & 3.50 \\
\hline
\end{tabular}

Notes: (numbers in red are incomplete data)

Tests $080806-1$ and $080806-2$ were interrupted by power outages and PS data lost

Test $080906-1$ was interrupted by reference electrode problem after 2.07 days

Test 082106 was interrupted after 12 hours due to bubble in Luggin capillary

\section{$E_{\text {corr }}$ measurements}

The $\mathrm{E}_{\text {corr }}$ values measured under aeration demonstrated vastly different results for the borated stainless steels and the C4-Gd alloy. The $\mathrm{E}_{\text {corr }}$ values were observed to shift positive of $0.1 \mathrm{~V}$ for the 304B4 alloy and as far positive as $0.178 \mathrm{~V}$ (Test 072606). Most tests showed $\mathrm{E}_{\text {corr }}$ values for 304B4 under aerated conditions between 0 and $0.2 \mathrm{~V}$. These values should not be considered equilibrated as the potential were trending positive at the end of the test. The values decreased to between $-0.4 \mathrm{~V}$ and $-0.25 \mathrm{~V}$ after $\mathrm{N}_{2}$ gas purge. The $\mathrm{E}_{\text {corr }}$ for the C4-Gd was unaffected by the aeration with values near $-0.3 \mathrm{~V}$ observed. Examples of $\mathrm{E}_{\text {corr }}$ versus time are shown for conditions of aeration (Figure 6) and $\mathrm{N}_{2}$ gas purge (Figure 7). The $\mathrm{E}_{\text {corr }}$ for the 304B4 alloy shows numerous negative excursions while being aerated. They are due to metastable (short-lived) pitting events. The $\mathrm{E}_{\text {corr }}$ for the C4-Gd alloy does not show this type of activity, likely due to the corrosion potential being pinned to more negative potentials. This pinning is attributed to the presence of the gadolinide phase. The corrosion of the gadolinide phase will be discussed below.

Using the measured $\mathrm{E}_{\text {corr }}$ values observed for the 304B4 alloy, the potential for the PS tests was chosen to be $0.1 \mathrm{~V}$. One test for 304B4, Test 072606 , had a final $\mathrm{E}_{\text {corr }}$ value above 0.1 $\mathrm{V}$. As will be discussed in the PS measurement section below, a more positive value of $0.2 \mathrm{~V}$ 
was investigated as well. While the $\mathrm{C} 4-\mathrm{Gd}$ showed much more positive values for $\mathrm{E}_{\text {corr }}$, it is anticipated that the eventual removal of the surface intersecting gadolinide phase would result in $\mathrm{E}_{\text {corr }}$ values more like that of the 304B4.

Four tests were performed for the A978 alloy but are not shown. These tests had issues with specimen contacts as will be discussed in the PS measurement section below.

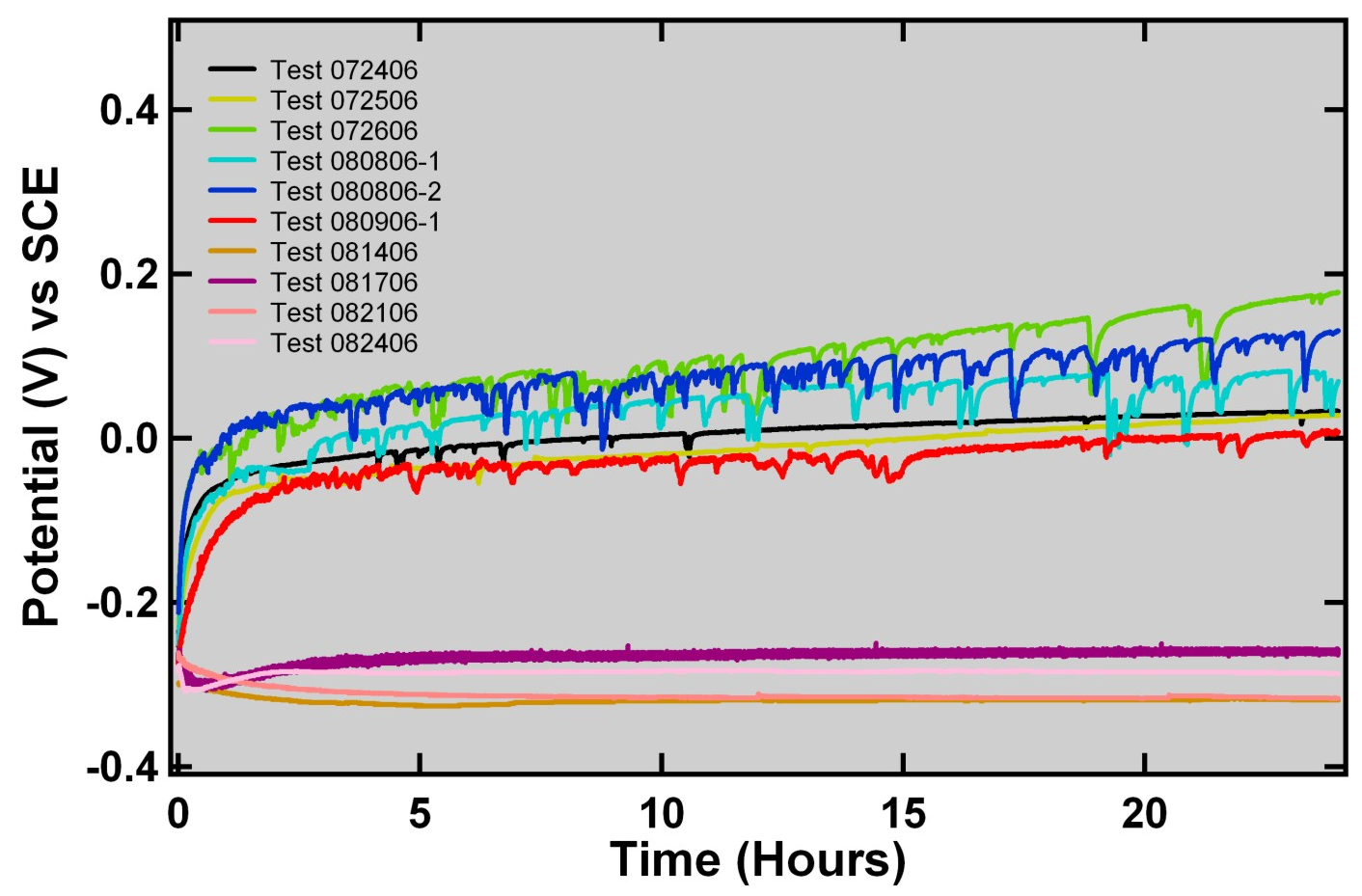

Figure 6: $\mathrm{E}_{\text {corr }}$ versus time for aerated cell. Tests 072406, 072506, $072606080806-1,080806-2$, and 080906-1 are 304B4 specimens and test 081406, 081706, 082106, and 082406 are C4-Gd specimens. 


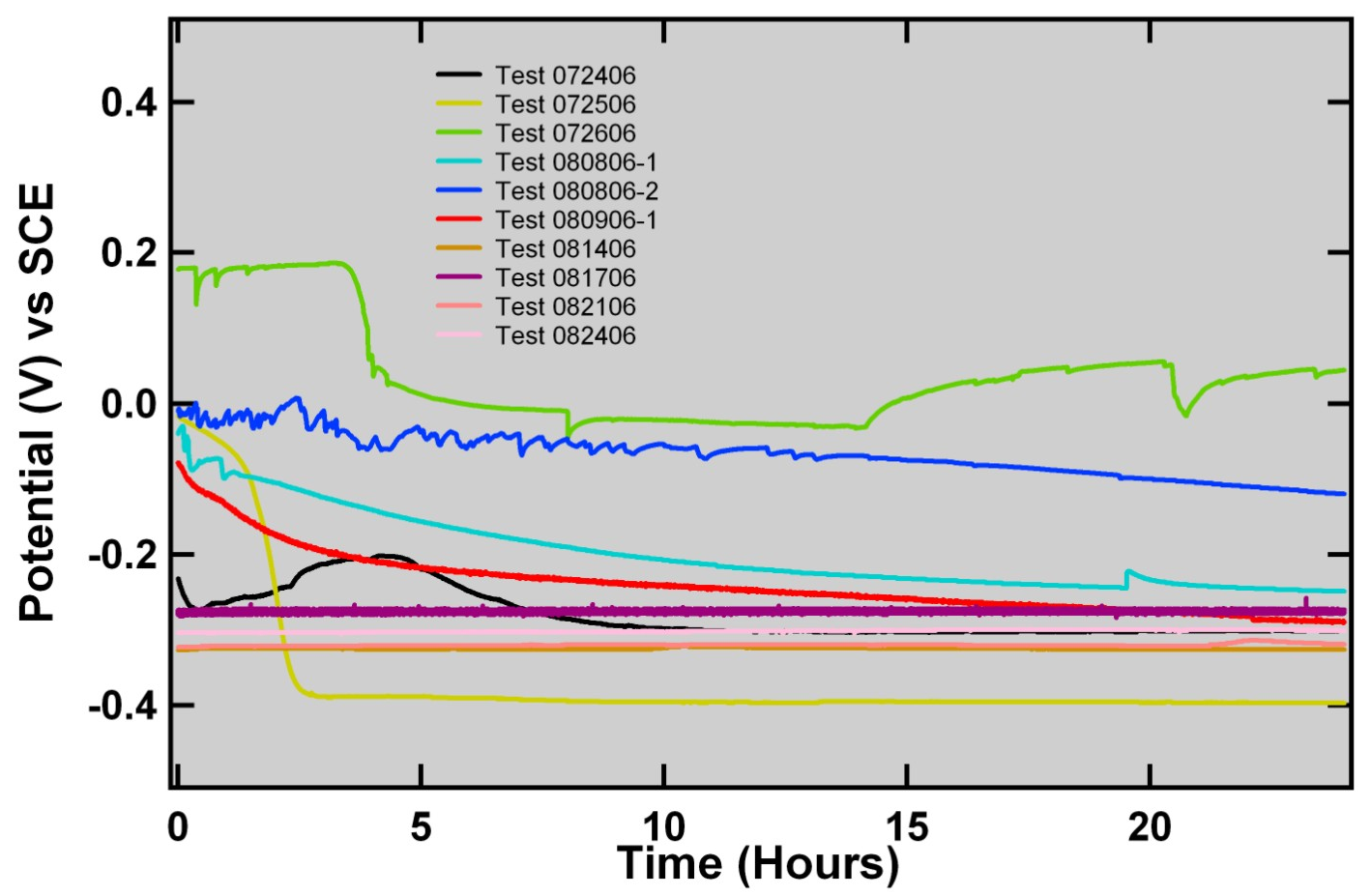

Figure 7: $\mathrm{E}_{\text {corr }}$ versus time for $\mathrm{N}_{2}$ purged cell. Test 072406, 072506, 072606, 080806-1, 0808062, and 080906-1 are 304B4 specimens and Tests 081406. 081706, 082106, and 082406 are C4-

Gd specimens.

\section{LPR measurements}

The corrosion rates calculated for LPR curves show that the 304B4 has lower corrosion rates than the C4-Gd alloy. It is believed that the rates for the C4-Gd alloy are measuring the dissolution of the gadolinide secondary phase and are not indicative of the general corrosion rate of the base material. Table 4 shows the corrosion rates calculated from the LPR data. These results show the same trends observed in the PS tests below.

Table 4: Corrosion rates from LPR measurements.

\begin{tabular}{|c|c|c|c|}
\hline Test ID & $\begin{array}{c}\text { Specimen } \\
\text { Type }\end{array}$ & $\begin{array}{c}\text { Avg CR } \\
(\mu \mathrm{m} / \mathbf{y r})\end{array}$ & SD \\
\hline 72406 & 304 B4 & 0.221 & 0.070 \\
\hline 72506 & 304 B4 & 0.276 & 0.057 \\
\hline 72606 & 304 B4 & 0.067 & 0.005 \\
\hline $080806-1$ & 304 B4 & 0.197 & 0.072 \\
\hline $080806-2$ & 304 B4 & 0.115 & 0.011 \\
\hline $080906-1$ & 304 B4 & 0.647 & 0.049 \\
\hline 81406 & C4-Gd & 24.1 & 3.1 \\
\hline 81706 & C4-Gd & 5.19 & 0.067 \\
\hline 82106 & C4-Gd & 21.1 & 1.8 \\
\hline 82406 & C4-Gd & 1.85 & 0.960 \\
\hline
\end{tabular}




\section{PS measurements}

The PS measurements were performed primarily at $0.1 \mathrm{~V}$, with $0.2 \mathrm{~V}$ used to determine the effect of higher potential in some tests. These values were derived from the $\mathrm{E}_{\mathrm{corr}}$ measurements under aeration as described above. Figure 8 shows a plot of curves for the 304B 4 and C4-Gd alloys. In the case of 304B4, the current dropped to very low values at both potentials. The current translated into corrosion rates less than $100 \mathrm{~nm} / \mathrm{yr}$, i.e. very passive behavior. Spikes up to several hundred $\mathrm{nA} / \mathrm{cm}^{2}$ were observed during the tests, indicating metastable pitting activity but no long-lived current excursions were observed. The total charge values were also very low, another indication that very little corrosion had occurred. Test 080806-2 was run at a higher potential of $0.2 \mathrm{~V}$ with similar behavior, however a power outage resulted in the test ending early and the data was lost. The data for the C4-Gd alloy indicated lower general corrosion performance. This is likely due to the slow dissolution of the gadolinide phase. Steady decreases in current were observed for all C4-Gd alloy tests. Longer test times or secondary phase removal prior to testing should be considered to evaluate the true performance of the C4-Gd alloy.

Four tests were run with the A978 alloy. These are not shown in Figure 8 due to issues with these tests stemming from the design of the electrical contact. The first two tests utilized the epoxy coated contacts which delaminated after several days of exposure. After delamination, the contact was corroded and contributed to the measured current. The second two tests used an exposed Pt wire contact that appeared to affect the potential and current during the tests. Small negative currents were observed for these final tests that are likely indicative of reactions on Pt. One crevice corrosion site was observed for Test 080206.

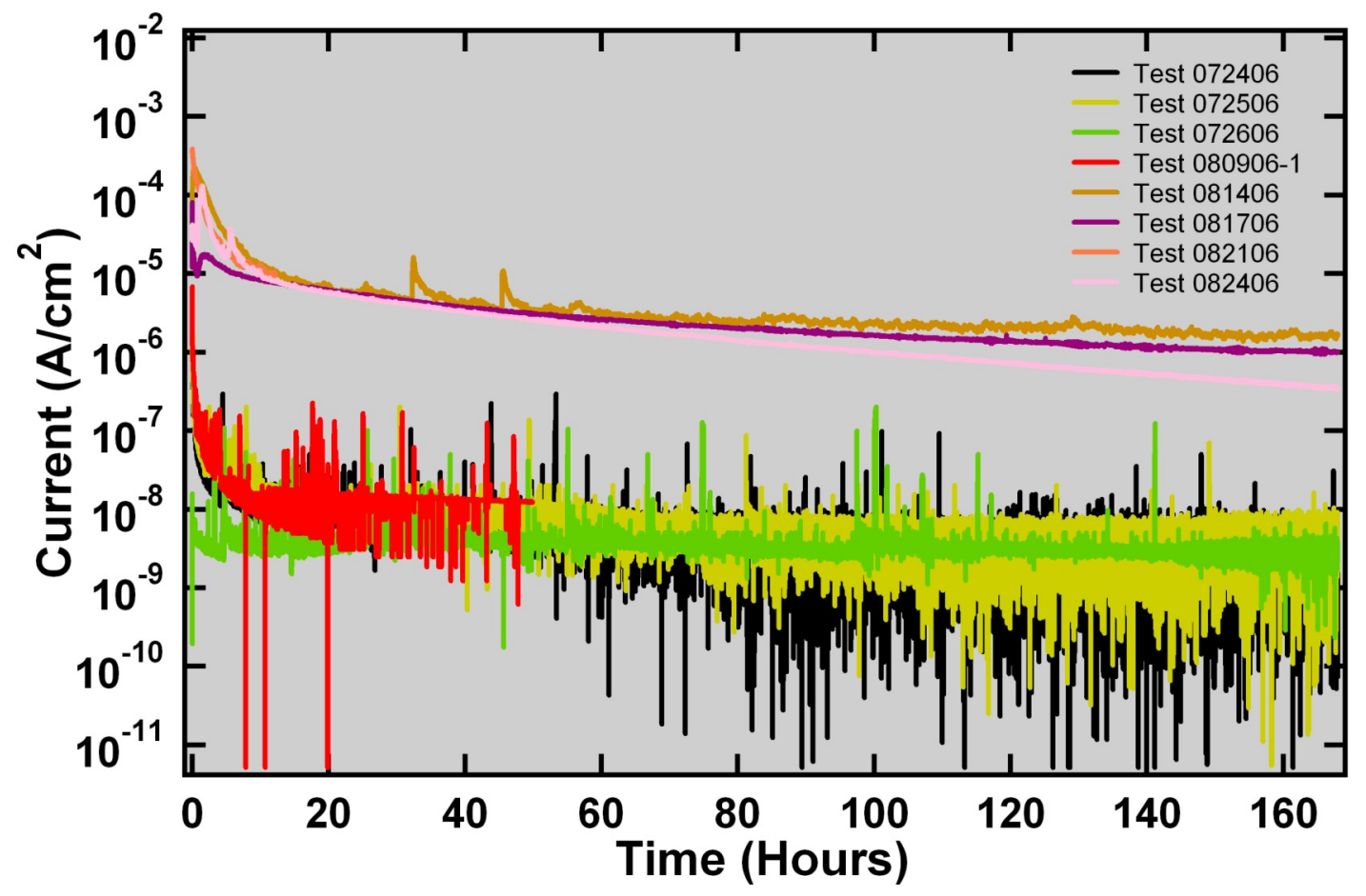

Figure 8: Current versus time plots for PS tests. Test 072406, 072506, 072606, and 080906-1 are for 304B4 specimens and Tests 081406, 081706, 082106, and 082406 are C4-Gd specimens. Note that Tests 080906-1 and 082106 are not complete 7 day data sets. 


\section{Post-test analysis}

Analysis of the specimens and test solutions after the tests involved visual inspection, gravimetric analysis, LOM, and scanning electron microscopy (SEM). Table 5 provides brief post-test observations for the 304B4 and C4-Gd specimens. The solutions were clear and colorless except for Test 082106 test where the reference failed, resulting in unknown potentials (transpassive corrosion). The solution was yellow from dissolved chromate ions. The specimens were free of extensive damage to the surface as shown in Figure 9. The specimens were shiny with evidence of slight hazing due to secondary phase removal for the C4-Gd specimens (Figure 9). Some of the C4-Gd specimens showed staining under the crevice former as well from gadolinide removal.

Representative LOM images of the damage from each of these alloys are shown in Figure 10. In several cases, small pits or light etching was observed under a crevice former for 304B4 specimens (Figure 10). The most damage was observed for Tests 080806-1 and 080806-2 which were incomplete tests and are not shown. For C4-Gd tests, the removal of the gadolinide phase was partial for completed tests (Tests $081406,081706,082406$ ). No evidence of primary phase corrosion was found for the $\mathrm{C} 4-\mathrm{Gd}$ alloys. Figure 10 shows that there was a partial removal of the Ni-Cr-Mo-Gd secondary phase for Test 081406.

The specimen surfaces were also observed with SEM in both secondary electron (SE) and backscatter electron (BSE) modes. Images of 304B4 are shown in Figure 11. Figure 11A shows a large shallow area of damage while the other images are of smaller pits less than $100 \mu \mathrm{m}$ in size. The BSE images show the numerous $\mathrm{Cr}_{2} \mathrm{~B}$ phases (darker grey) in the material. The darker areas are corrosion sites or accumulated scale. Figure 12 show the C4-Gd alloy after corrosion testing. The bright areas are due to the gadolinide phase particles, which appear to be partially removed. Figure $12 \mathrm{C}$ shows the area of an entire MCA tooth where the gadolinide under the tooth is removed while the surrounding material is still intact. Figure 12A-B shows the edge of the crevice former where the inner gadolinides are removed while gadolinides outside the crevice appear intact.

Additional SEM work was performed to show the microstructure of the secondary phases after testing. The SEM images were obtained in BSE mode to enhance the contrast of the secondary phase. Figure 13A-B shows the microstructure of the A978 alloy (Test 080206) with large secondary phase particles compared with the 304B4 specimen (Test 080806-1) having smaller more evenly distributed secondary phase particles. The SEM image of the C4-Gd specimen from Test 082406 shows the partial removal of the gadolinide phase. Small cavities remain from particles that were dissolved. No evidence of localized corrosion damage extending beyond these cavities was found. 
Table 5: Post-test PS test observations

\begin{tabular}{|c|c|c|c|l|}
\hline Test ID & Alloy & Solution & $\begin{array}{c}\text { Solution } \\
\text { Observations }\end{array}$ & \multicolumn{1}{|c|}{$\begin{array}{c}\text { Specimen } \\
\text { Observations }\end{array}$} \\
\hline 072406 & $304 \mathrm{~B} 4$ & B1 & Clear and colorless & One small crevice pit \\
\hline 072506 & $304 \mathrm{~B} 4$ & B3 & Clear and colorless & $\begin{array}{l}\text { Light pitting under several } \\
\text { crevice formers }\end{array}$ \\
\hline 072606 & $304 \mathrm{~B} 4$ & B1 & Clear and colorless & one crevice area (etched) \\
\hline $080806-1$ & $304 \mathrm{~B} 4$ & B1 & Clear and colorless & $\begin{array}{l}\text { Etching under several crevice } \\
\text { formers }\end{array}$ \\
\hline $080806-2$ & $304 \mathrm{~B} 4$ & B1 & Clear and colorless & $\begin{array}{l}\text { Etching and pitting under } \\
\text { several crevice formers }\end{array}$ \\
\hline $080906-1$ & $304 \mathrm{~B} 4$ & B3 & Clear and colorless & No crevice corrosion \\
\hline 081406 & C4-Gd & B1 & Clear and colorless & $\begin{array}{l}\text { Partial surface gadolinide } \\
\text { removal }\end{array}$ \\
\hline 081706 & C4-Gd & B3 & Clear and colorless & $\begin{array}{l}\text { Partial surface gadolinide } \\
\text { removal }\end{array}$ \\
\hline 082106 & C4-Gd & B1 & Clear and yellow & $\begin{array}{l}\text { Heavy etching on boldly } \\
\text { exposed surface, removal of } \\
\text { surface gadolinides }\end{array}$ \\
\hline 082406 & C4-Gd & B3 & Clear and colorless & $\begin{array}{l}\text { Partial surface gadolinide } \\
\text { removal }\end{array}$ \\
\hline
\end{tabular}

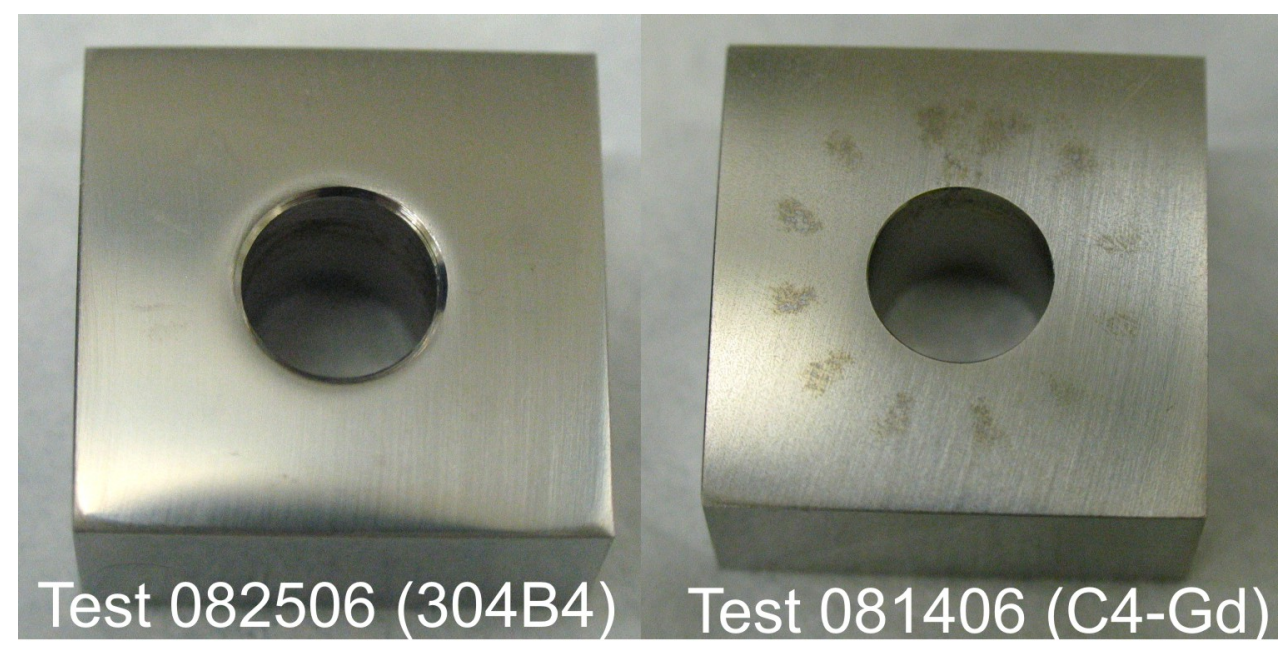

Figure 9: Photographs of PS test specimens after testing. 


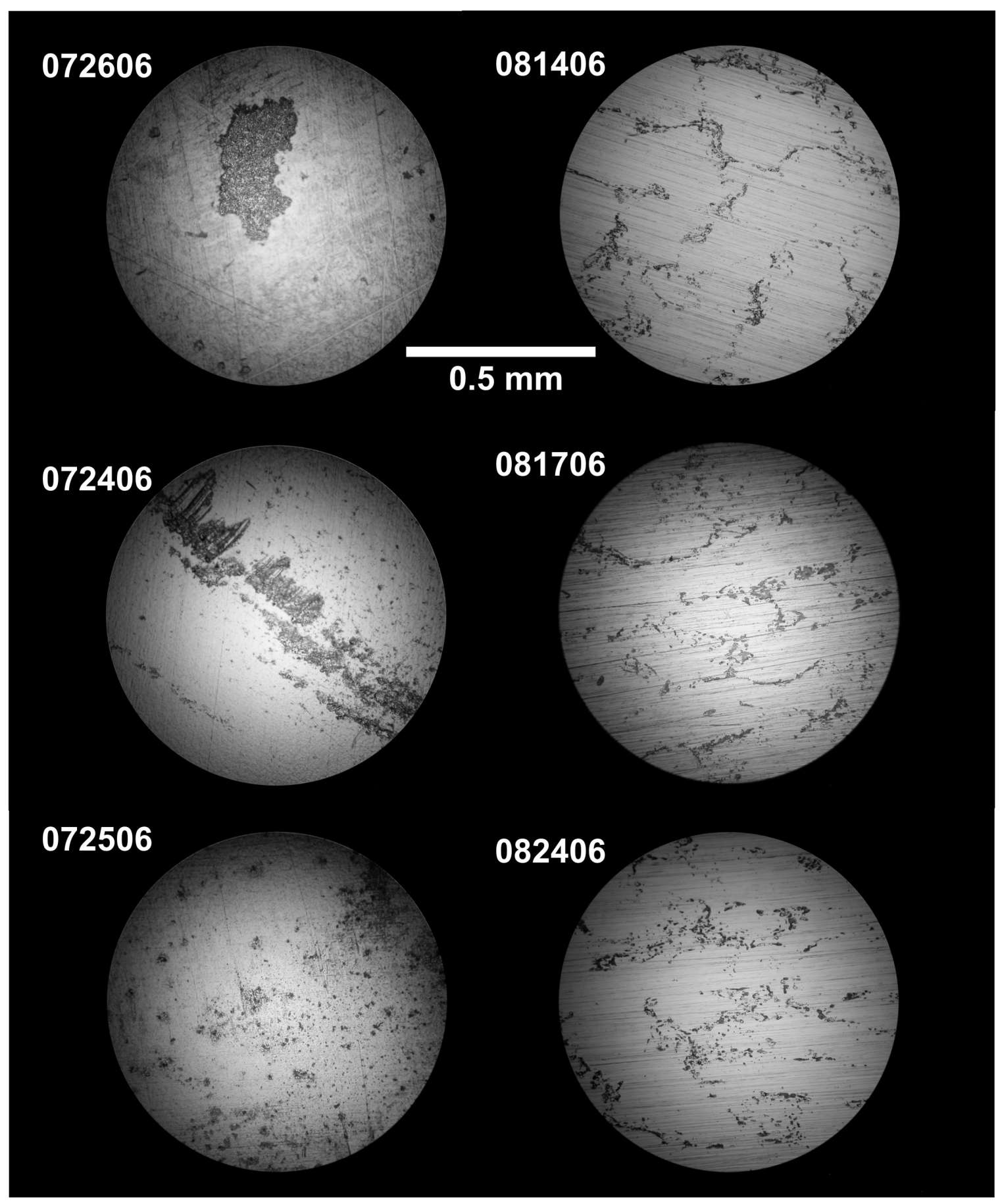

Figure 10: LOM images of selected specimens showing damage to the surface. Tests 072606, 072406, and 072506 are 304B4 specimens and Tests 081406,081706 and 082406 are C4-Gd specimens. All images were taken at a magnification factor of $200 \mathrm{X}$. 

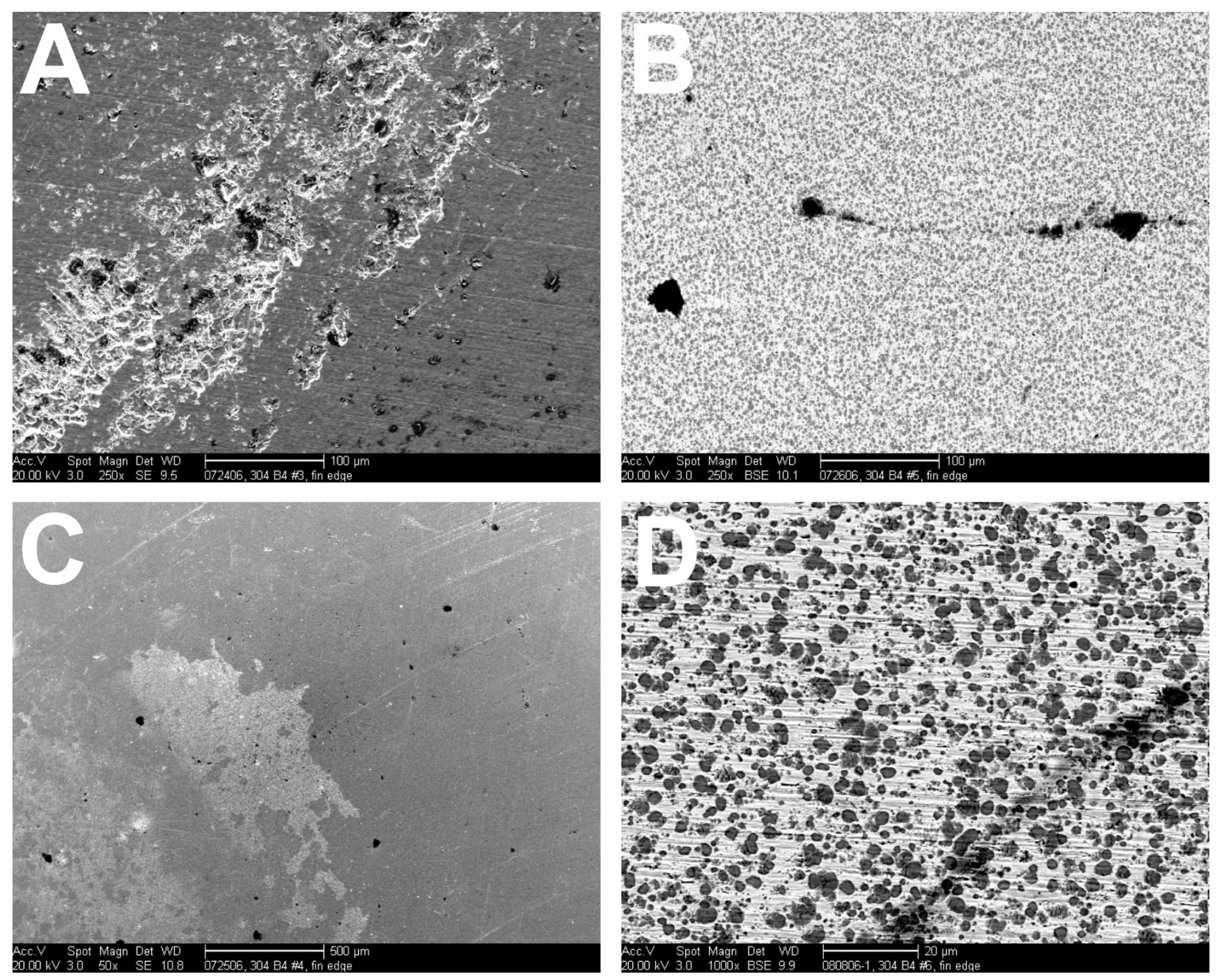

Figure 11: SEM images of 304B4 alloy corrosion specimens following testing. The images were obtained in SE $(\mathrm{A}+\mathrm{C})$ and $\mathrm{BSE}(\mathrm{B}+\mathrm{D})$ modes. 

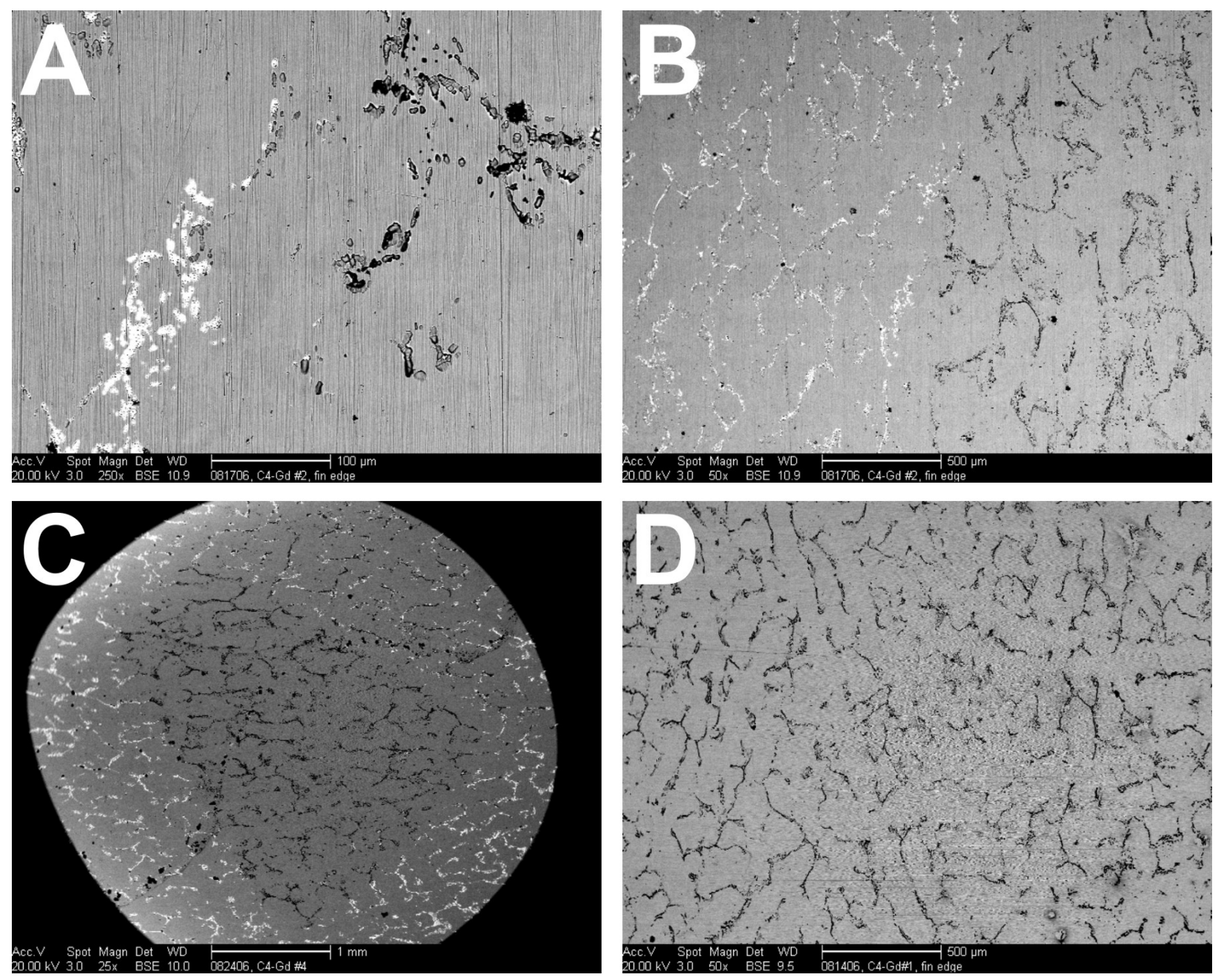

Figure 12: SEM images of C4-Gd alloy corrosion specimens following testing. The images were obtained in BSE mode. 

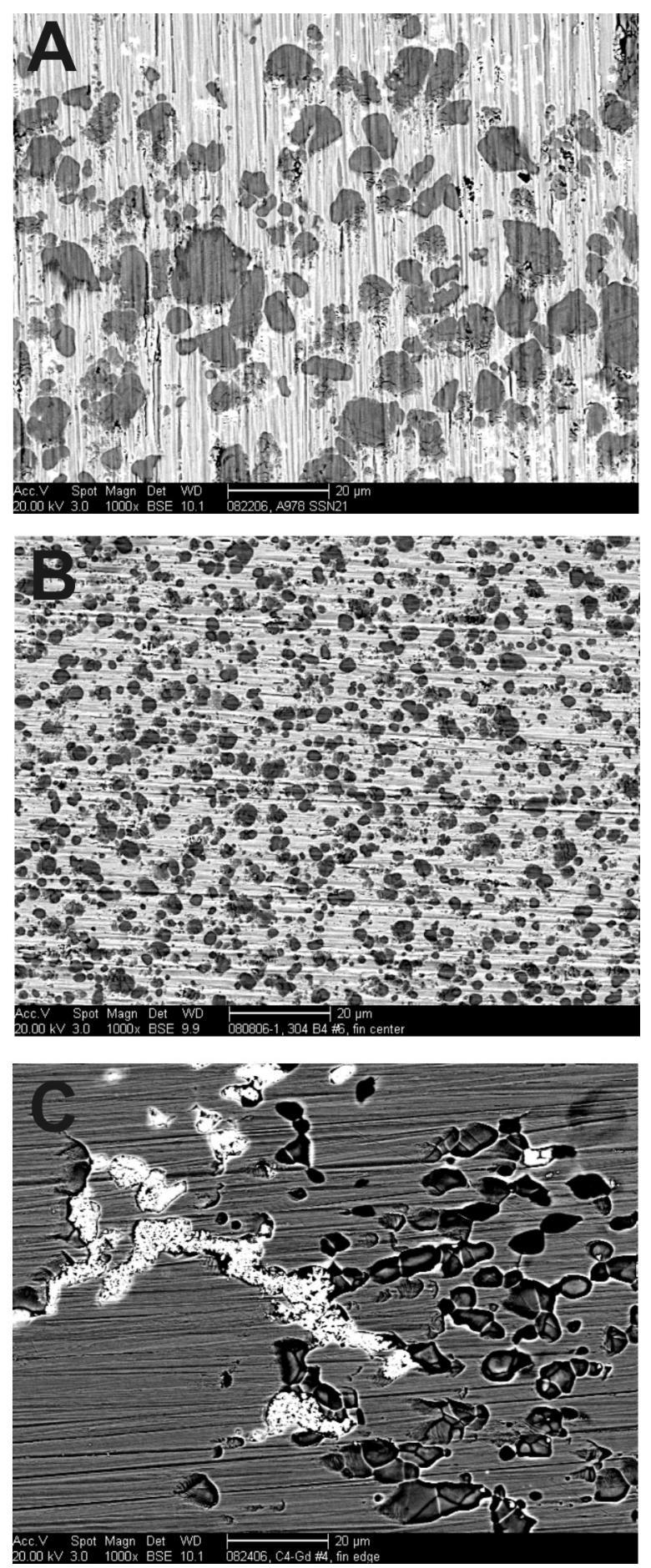

Figure 13: SEM images obtained in BSE mode showing the secondary phase particles for A) A978, B) 304B4, and C) C4-Gd alloys.

\section{Conclusions}

Corrosion testing of three neutron absorbing alloys, Carpenter 304B4, Neutronit A978, and Ni-Cr-Mo-Gd (C4-Gd) alloys, was performed using electrochemical testing methods. The conditions were based on those expected for a waste package should the outer barrier breech and 
the internals exposed to moisture. Potentiodynamic (PD) tests were performed to determine the localized characteristics of the materials. Measurement of the corrosion potential $\left(\mathrm{E}_{\mathrm{corr}}\right)$ was used to determine the equilibration potentials under aeration to determine values for performing potentiostatic (PS) tests. The PS tests hold the potential of the specimen at a value as determined from the $\mathrm{E}_{\text {corr }}$ testing while measuring the current. The current from this test can be used to determine the corrosion rate and/or propensity toward localized corrosion. In addition, linear polarization resistance (LPR) tests were performed as a second method to determine the corrosion rate. Damage to the specimens was observed using photography, light optical microscopy (LOM), and scanning electron microscopy (SEM).

While acceptable results were obtained for 304B4 and C4-Gd alloys, experimental problems occurred for the A978 alloy in PS tests. These problems stemmed from having to adapt long term exposure test specimens to electrochemical testing. The problem was due to the method used for specimen contact.

The testing performed on these neutron absorbers have shown behavior that has contradicted some of the previous work on these types of alloys. ${ }^{8,18}$ However, in those previous tests the conditions are more aggressive (temp, $\mathrm{pH}$, ionic content, ect.) than those used here. The tests here contain very low ionic contents and/or moderate $\mathrm{pH}$ values. Thus very passive conditions were observed for the 304B4 SS in all cases. There was some evidence of metastable pitting on the borated stainless steel though sustained pitting events were not observed. Several 304B4 specimens showed significant but isolated damage under the crevice formers. It is difficult to determine if the corrosion occurred prior to the PS tests, particularly during aeration where the potentials were fairly positive on the specimens that may not yet have been fully passivated. Some further investigation of this is warranted. Ideally, the tests would extend conditions such that the localized corrosion initiation threshold in potential, temperature, and solution composition $\left(\mathrm{Cl} / \mathrm{NO}_{3}\right.$ ratio, $\left.\mathrm{pH}\right)$ are known.

The results of the Ni-Cr-Mo-Gd alloy tests are less clear. The general corrosion rate was several orders of magnitude higher than for the 304B4 material. However, this corrosion rate is determined by the very reactive gadolinide secondary phase. ${ }^{19}$ High corrosion rates of the gadolinide phase have been observed in earlier tests. ${ }^{19}$ The secondary phase $\left(\mathrm{Cr}_{2} \mathrm{~B}\right)$ of the borated stainless steel appears to be stable, likely due to the $\mathrm{Cr}$ content and thus does not contribute to the corrosion directly. It is known to reduce the overall localized corrosion properties due to the sequestration of $\mathrm{Cr}$ from the primary, austenite phase. ${ }^{8,18}$ Evidence shows that the gadolinide phase was not fully removed in these tests, thus the final PS corrosion current values (and calculated corrosion rate) are affected by continued corrosion of the gadolinide phase. It is anticipated that the general corrosion performance would improve after the full removal of this phase. As shown in previous work the primary phase was very resistant to localized corrosion. In addition, an increase in the Cr composition in the Ni-Cr-Mo-Gd alloy to a similar level as in the 304B4 and A978 is expected to improve the corrosion resistance of the primary phase further. The benefits of the Ni-based alloy would be useful for more aggressive conditions than tested here.

\footnotetext{
${ }^{18}$ D.A. Moreno, B. Molina, C. Ranninger, F. Montero, and J. Izquierdo, "Microstructural Characterization and Pitting Corrosion Behavior of UNS S30466 Borated Stainless Steel”, Corrosion 60 (2004) 573.

${ }^{19}$ T.E. Lister, R.E. Mizia, P.J. Pinhero, T.L. Trowbridge, and K.B. Delezene-Briggs, "Studies of the Corrosion Properties of Ni-Cr-Mo-Gd Neutron-Absorbing Alloys”, Corrosion 61 (2005) 706.
} 


\begin{abstract}
Appendix
A978 PS Test Data

This supplemental report provides data from tests of A978 specimens. These tests were not included in the main report due to experimental issues with the design of the specimen electrical contact. Two methods were used to make the specimen contact to the non-standard specimens. Specimens for Tests 072706 and 080206 were attached using short Pt wire spot welded to a corner of the coupon and a longer plastic insulated wire soldered to that wire. Then the entire exposed wire was insulated using Dexter Hydrosol epoxy. Problems were noted during the testing with delamination of the epoxy leading to corrosion of the wire and solder. With these tests, the initial part of the experiment ( $\mathrm{E}_{\text {corr }}$ measurement, LPR) is likely not affected. However, the PS data is likely affected. It is not known when the delamination affected the test, so the data is of limited use. A second attachment method used a Pt wire (corrosion resistant but not unreactive) spot welded to a corner of the coupon and extended out of the cell. No coating was used, leaving the Pt wire and spot weld damage exposed to solution. Tests 082206 and 082806 used this contact. This contact was stable, but the Pt wire was exposed and thus can contribute to the measured current. Table A1 shows data tabulated from PS testing of A978 specimens.

Figure A1-2 shows the $E_{\text {corr }}$ measurement for the A978 tests under aerated and $\mathrm{N}_{2}$ purge. There does not appear to be a consistent common behavior in the $\mathrm{E}_{\text {corr }}$ data except of the two epoxy coated specimens under $\mathrm{N}_{2}$ purge.

Figure A3 shows the PS data obtained from the four A978 specimens. The two specimens using an epoxy coating have much higher current. After examination of the specimens after the test (Figure 4) it was obvious that the contact to the specimens was corroded. The specimens using only a bare Pt wire contact showed low negative currents, with short excursion positive due to localized corrosion. This negative current is obviously due to the exposed Pt wire, likely an electrochemical reaction with dissolved species. Thus, in all cases a corrosion rate cannot be ascertained as the current is dominated by other reactions at the contact wires. Since the net current was negative, this suggests that the anodic corrosion current for the A978 was fairly low.

Figure A4 shows macro photographs of the specimen surfaces after testing. While the electrochemical data not very useful, the damage to the surface observed during the test is likely to be what would occur on a test using the properly configured crevice specimen. The exception might be Test 072706 where the contact was so corroded that the specimen was not in electrical contact for much of the test. A thick brown film coated the surface of the Test 072706 specimen and the solution was clouded with precipitate. The film appears to be from the corrosion of the solder and wire of the contacting lead. Significant crevice corrosion was observed only on Test 080206 and 082206 . LOM of damage to these specimens under the crevice formers are shown in Figure A5. There was no significant damage to Test 072706 and 082806 specimens.
\end{abstract}




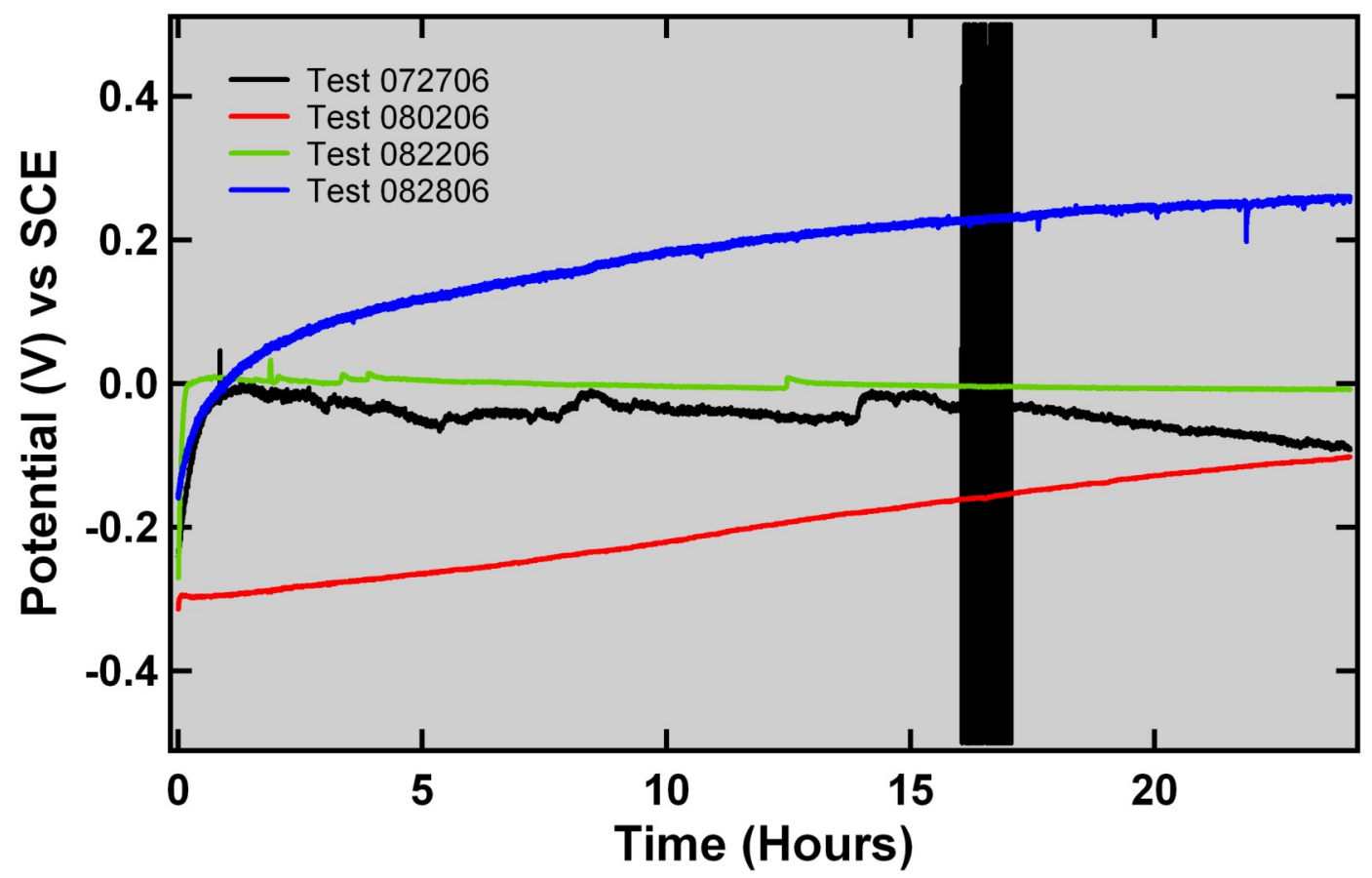

Figure A1: Plots of $\mathrm{E}_{\text {corr }}$ versus time for A978 specimens with aeration.

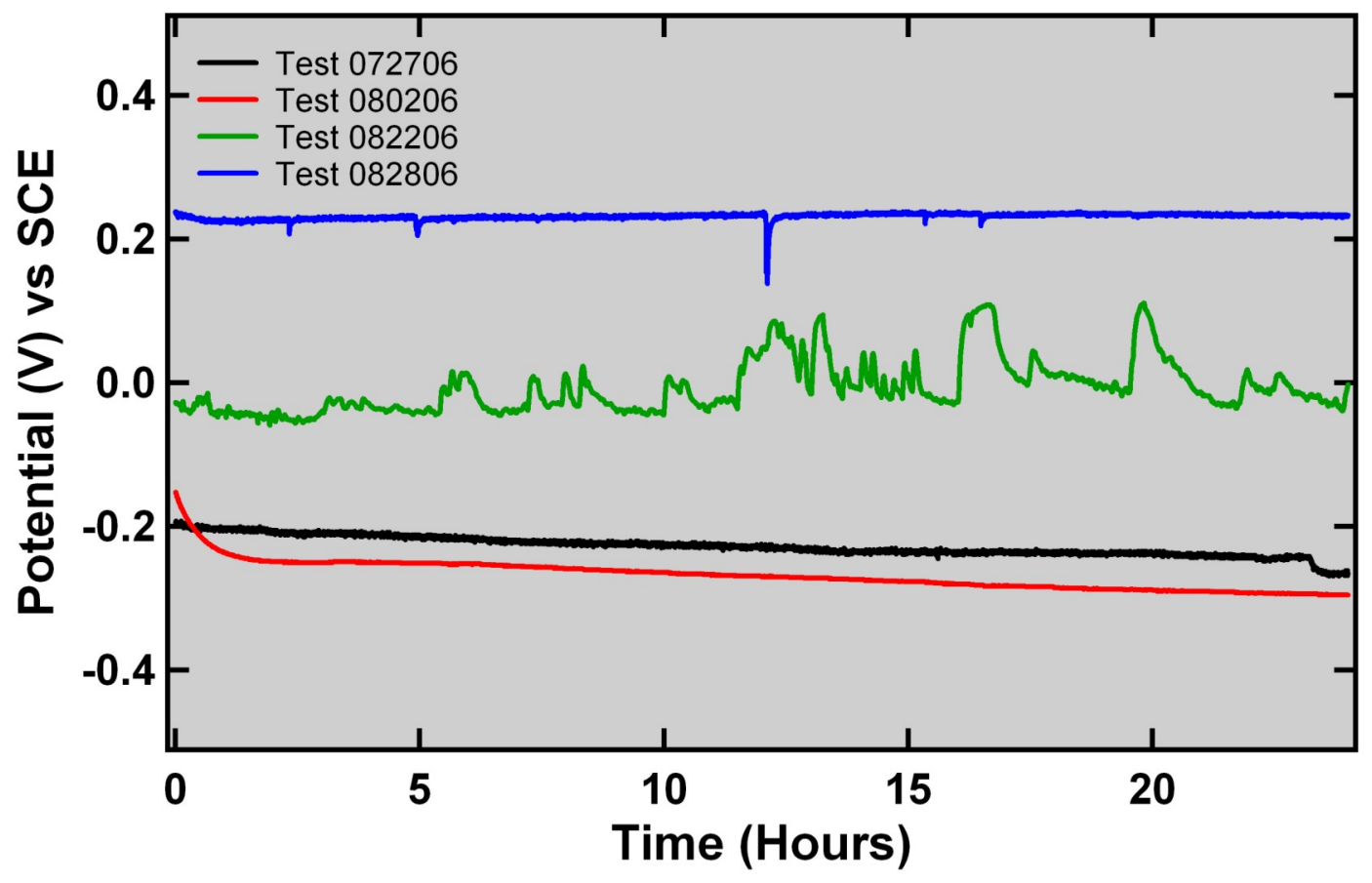

Figure A2: Plots of $E_{\text {corr }}$ versus time for A978 specimens during $\mathrm{N}_{2}$ purge. 


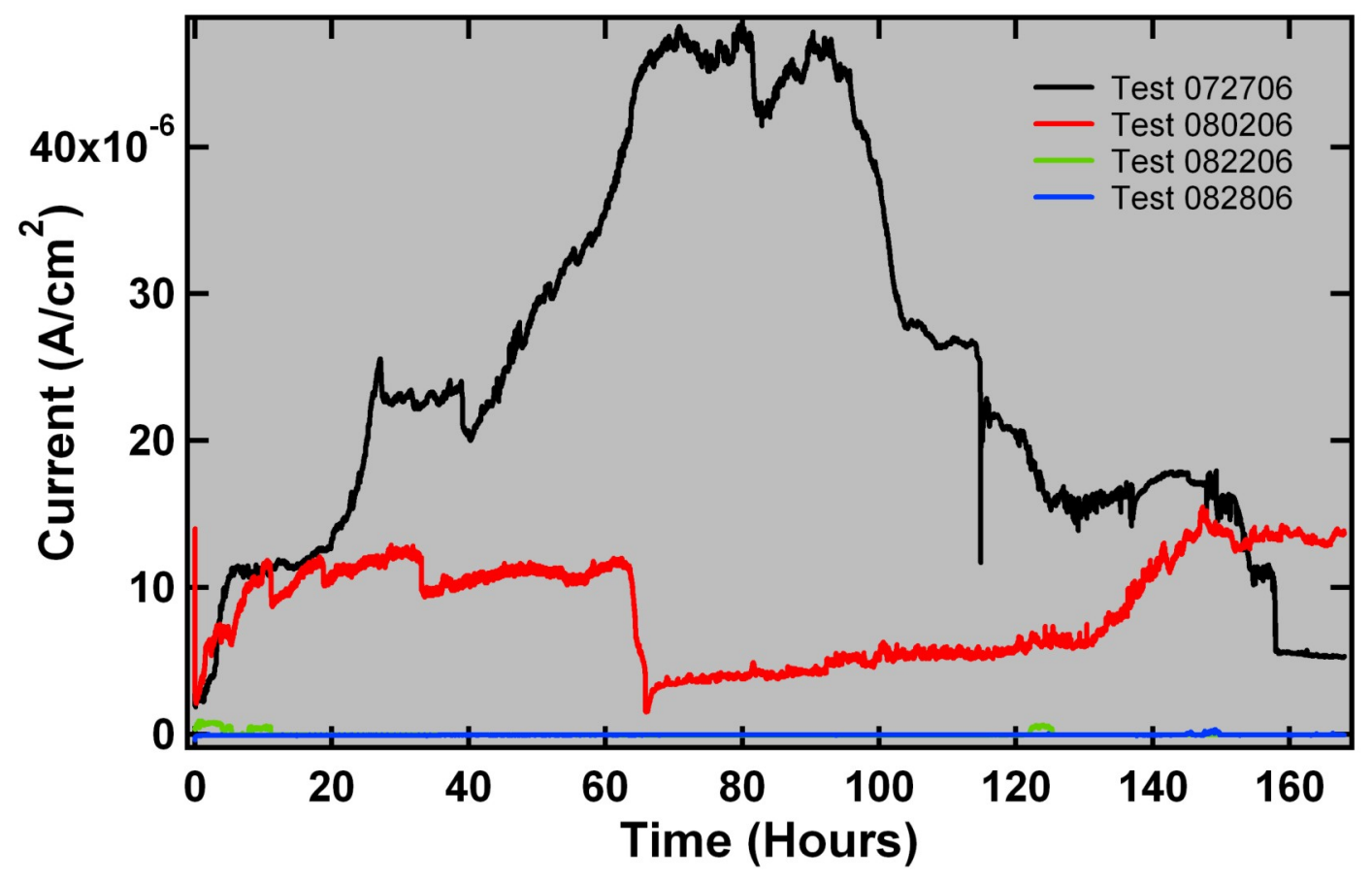

Figure A3: Plots of current versus time for PS tests of A978 specimens. 

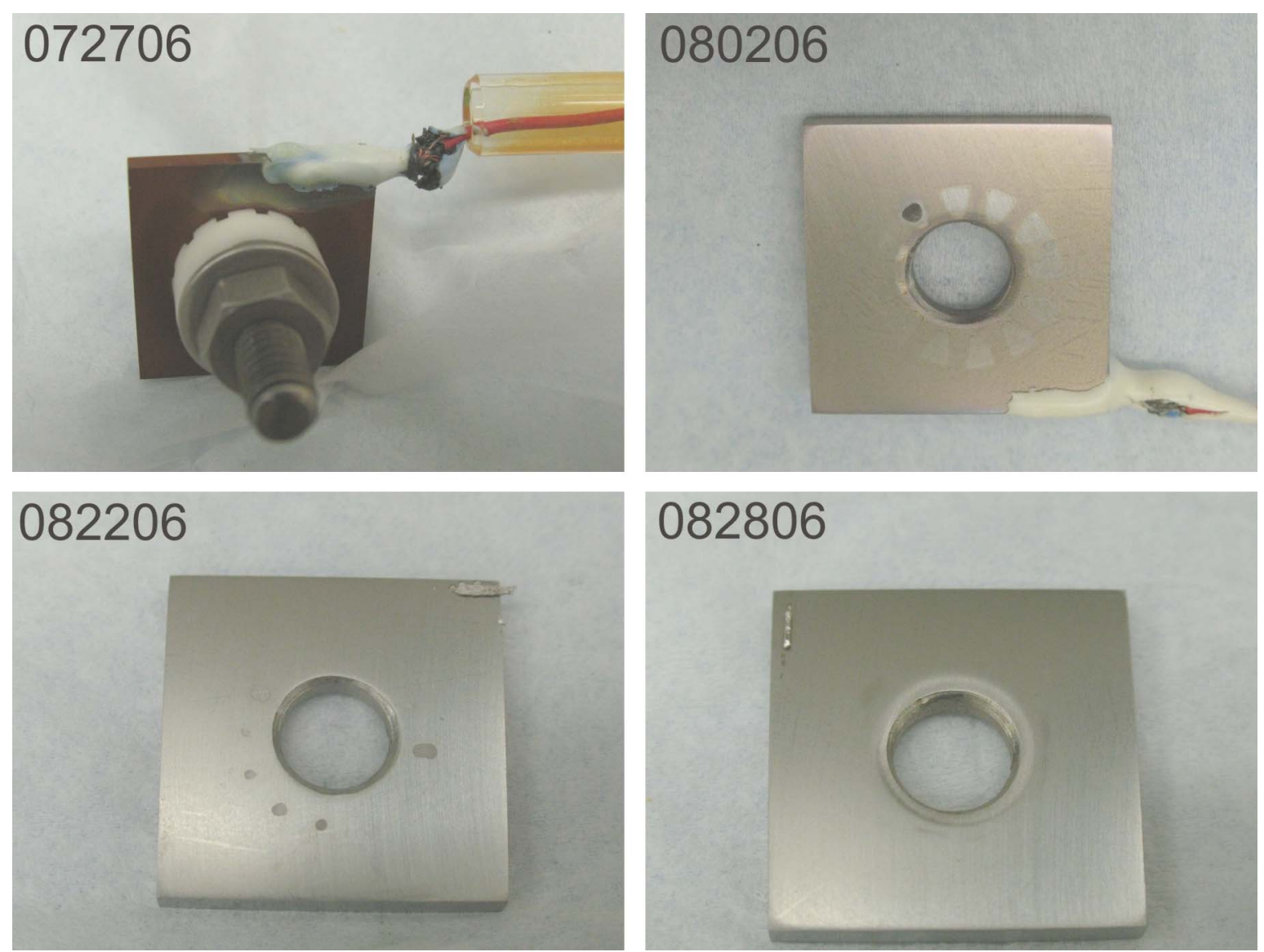

\section{6}

Figure A4: Macro photographs of A978 specimens after testing. Note that part of the Pt wire from the Tests 082206 and 082806 remains in the corner of these specimens. 


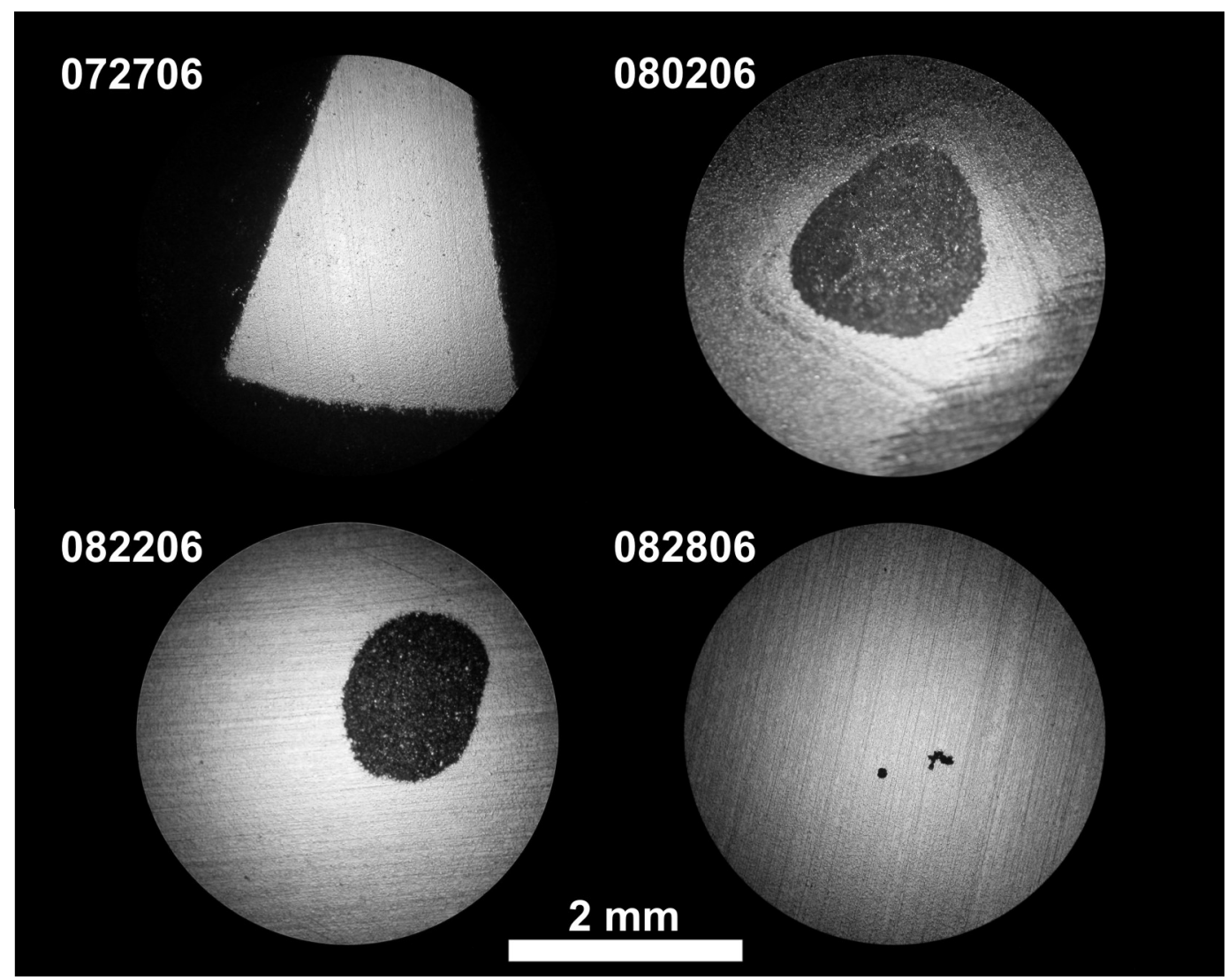

Figure A5: LOM images of A978 specimens after testing 


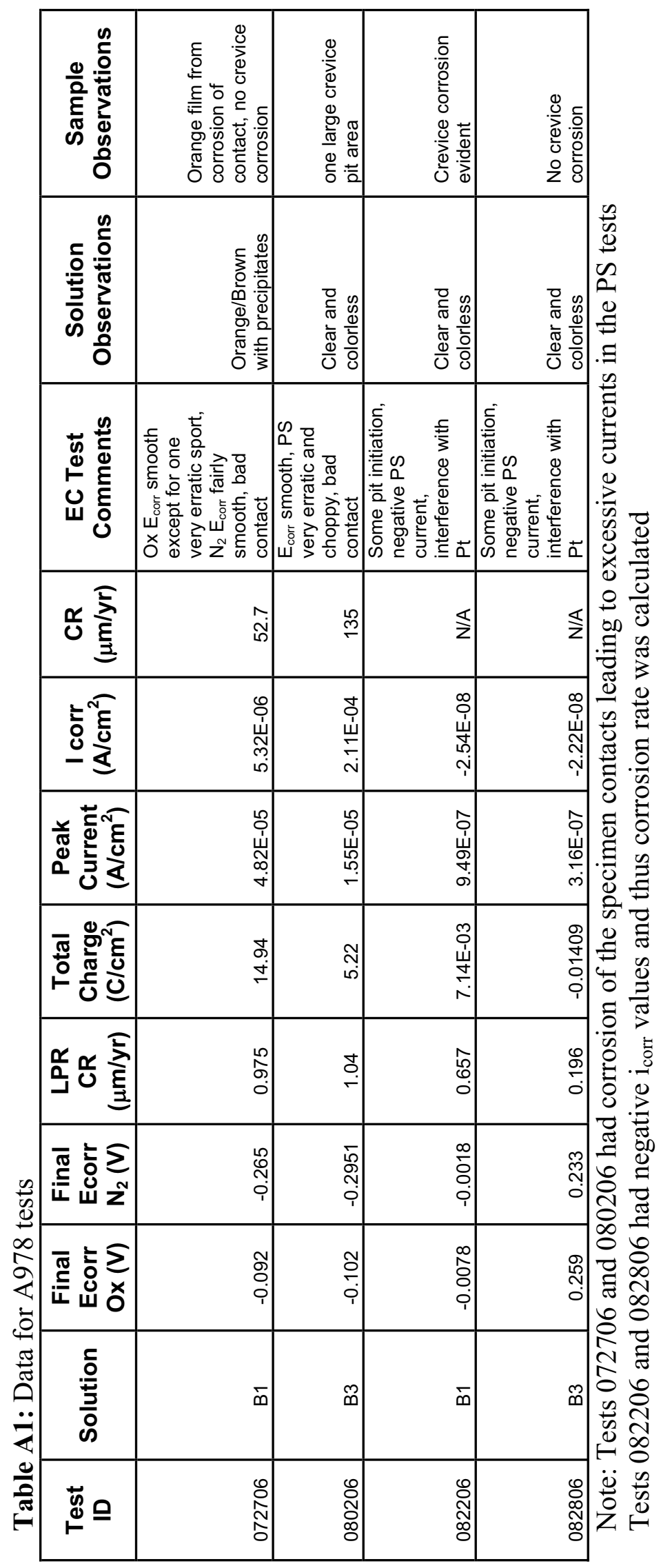

